\title{
Trends in oligomannosylation and a1,2-mannosidase expression in human cancers
}

\author{
Sayantani Chatterjee ${ }^{1}$, Julian Ugonotti ${ }^{1}$, Ling Y. Lee $^{1}$, Arun Everest-Dass ${ }^{2}$, Rebeca \\ Kawahara $^{1, *}$ and Morten Thaysen-Andersen ${ }^{1,3, *}$ \\ ${ }^{1}$ Department of Molecular Sciences, Macquarie University, Sydney, Australia \\ ${ }^{2}$ Institute for Glycomics, Griffith University, Gold Coast, Australia \\ ${ }^{3}$ Biomolecular Discovery Research Centre (BDRC), Macquarie University, Sydney, Australia \\ *Joint senior authors \\ Correspondence to: Rebeca Kawahara, email: rebeca.kawaharasakuma@ma.edu.au \\ Morten Thaysen-Andersen, email: morten.andersen@mq.edu.au \\ Keywords: oligomannose; al,2-mannosidase; cancer; glycomics; mass spectrometry \\ Received: May 12, $2021 \quad$ Accepted: August 18, $2021 \quad$ Published: October 12, 2021 \\ Copyright: (c) 2021 Chatterjee et al. This is an open access article distributed under the terms of the Creative Commons Attribution \\ License (CC BY 3.0), which permits unrestricted use, distribution, and reproduction in any medium, provided the original author and source \\ are credited.
}

\section{ABSTRACT}

Aberrant protein glycosylation is a prominent cancer feature. While many tumour-associated glycoepitopes have been reported, advances in glycoanalytics continue to uncover new associations between glycosylation and cancer. Guided by a comprehensive literature survey suggesting that oligomannosylation (Man $_{5-9}$ $\mathrm{GlcNAC}_{2}$ ) is a widespread and often regulated glycosignature in human cancers, we here revisit a valuable compilation of nearly $\mathbf{5 0 0}$ porous graphitized carbon LC-MS/ MS $\mathbf{N}$-glycomics datasets acquired across 11 human cancer types to systematically test for oligomannose-cancer associations. Firstly, the quantitative glycomics data obtained across 34 cancerous cell lines demonstrated that oligomannosylation is a pan-cancer feature spanning in a wide abundance range. In keeping with literature, our quantitative glycomics data of tumour and matching control tissues and new MALDI-MS imaging data of tissue microarrays showed a strong cancer-associated elevation of oligomannosylation in both basal cell $\left(p=1.78 \times 10^{-12}\right)$ and squamous cell $\left(p=1.23 \times 10^{-11}\right)$ skin cancer and colorectal cancer $\left(p=8.0 \times 10^{-4}\right)$. The glycomics data also indicated that some cancer types including gastric and liver cancer exhibit unchanged or reduced oligomannose levels, observations also supported by literature and MALDI-MS imaging data. Finally, expression data from public cancer repositories indicated that several a1,2-mannosidases are regulated in tumour tissues suggesting that these glycan-processing enzymes may contribute to the cancer-associated modulation of oligomannosylation. This omics-centric study has compiled robust glycomics and enzyme expression data revealing interesting molecular trends that open avenues to better understand the role of oligomannosylation in human cancers.

\section{INTRODUCTION}

Protein glycosylation, the addition of complex carbohydrates (glycans) to polypeptides, is a ubiquitous and energy-demanding post-translational modification important for a plethora of inter- and intracellular processes [1-5].

Asparagine (Asn, $N$ )-linked glycans display remarkable molecular heterogeneity despite being assembled from only few different monosaccharide building blocks including mannose (Man), galactose (Gal), fucose (Fuc), glucose (Glc), $N$-acetylglucosamine (GlcNAc) and $N$-acetylneuraminic acid (NeuAc) [5]. The template-less $N$-glycan biosynthesis begins in the endoplasmic reticulum (ER) by the transfer of immature Glc-capped glycan precursors to Asn residues located in consensus sequences of acceptor polypeptides and continues in the Golgi compartments. The biosynthesis 
involves successive glycan processing steps catalyzed by dozens of glycosyltransferases and glycoside hydrolases [6-8]. The resulting $N$-glycans that inherently display an extensive molecular heterogeneity are commonly classified as oligomannosidic-, hybrid- or complextype $N$-glycans [9-12], Figure 1A. Recently, truncated $N$-glycans not fitting into these three classes were reported from various human biospecimens including the inflammation- and cancer-associated paucimannosidic$\left(\mathrm{Man}_{1-3} \mathrm{GlcNAc}_{2} \mathrm{Fuc}_{0-1}\right)$ and the even shorter chitobiose core- $\left(\mathrm{GlcNAc}_{1-2} \mathrm{Fuc}_{0-1}\right)$ type $N$-glycans [12-16]. Several glycan species fit into each glycan type; for example, the M5-M9 glycans ( $\mathrm{Man}_{5-9} \mathrm{GlcNAc}_{2}$ ), the focus of this study, belong to the oligomannosidic-type $N$-glycans.

Oligomannosidic $N$-glycans are synthesized early in the biosynthetic pathway, Figure 1B. Several ER- and Golgi-resident $\alpha 1$,2-mannosidases catalyze the successive M9-to-M5 glycan processing. Specifically, mannosyloligosaccharide 1,2- $\alpha$-mannosidase 1A (MAN1A1, UniProtKB, P33908), mannosyl-oligosaccharide 1,2- $\alpha$-mannosidase IB (MAN1A2, O60476), endoplasmic reticulum mannosyl-oligosaccharide 1,2- $\alpha$-mannosidase (MAN1B1, Q9UKM7) and mannosyl-oligosaccharide 1,2- $\alpha$-mannosidase 1C (MAN1C1, Q9NR34) are known to trim the outer $\alpha 1,2-\mathrm{Man}$ residues of nascent glycoproteins to eventually form M5 devoid of any $\alpha 1,2-$ Man residues $[2,17]$. While these first processing steps play recognized roles in glycoprotein folding, maturation and trafficking, oligomannosylation is also involved in a host of less studied extracellular functions including cell-cell and cellextracellular matrix communication relevant for cancer and other immune-related processes including inflammation and pathogen infection [2, 18-21]. For example, reports have indicated the involvement of oligomannosylation in inflammatory processes caused by Mycobacterium tuberculosis [22, 23], urinary tract infections caused by Escherichia coli [24] and in autoimmune disorders such as systemic lupus erythromatosus [25].

Decades of intense research efforts have provided robust evidence supporting that altered protein glycosylation is an inherent feature of malignant transformation and other cancer traits, and have unearthed many glycan structures and glycoepitopes that play important roles in cancer [26]. Excellent reviews have summarized our current knowledge of the aberrant protein glycosylation underpinning cancer [26-31]. Altered expression patterns of fucosylation e.g., core and Lewis $^{\mathrm{X}}[32,33]$, sialylation e.g., $\alpha 2,3-$ and $\alpha 2,6-\mathrm{NeuAc}$ $[34,35]$ and glycan antennary branching e.g., bisecting $\beta 1,4-G 1 c N A c[36,37]$ are prominent examples of glycan features repeatedly associated with cancer.

Despite forming a considerable part of the $\mathrm{N}$-glycome, the mannose-terminating $\mathrm{N}$-glycans comprising both the oligomannosidic- and paucimannosidic-type have received comparably less attention in cancer research [21]. We recently used state-of-the-art glycomics to systematically document that paucimannosylation is an overlooked feature in many cancer types including

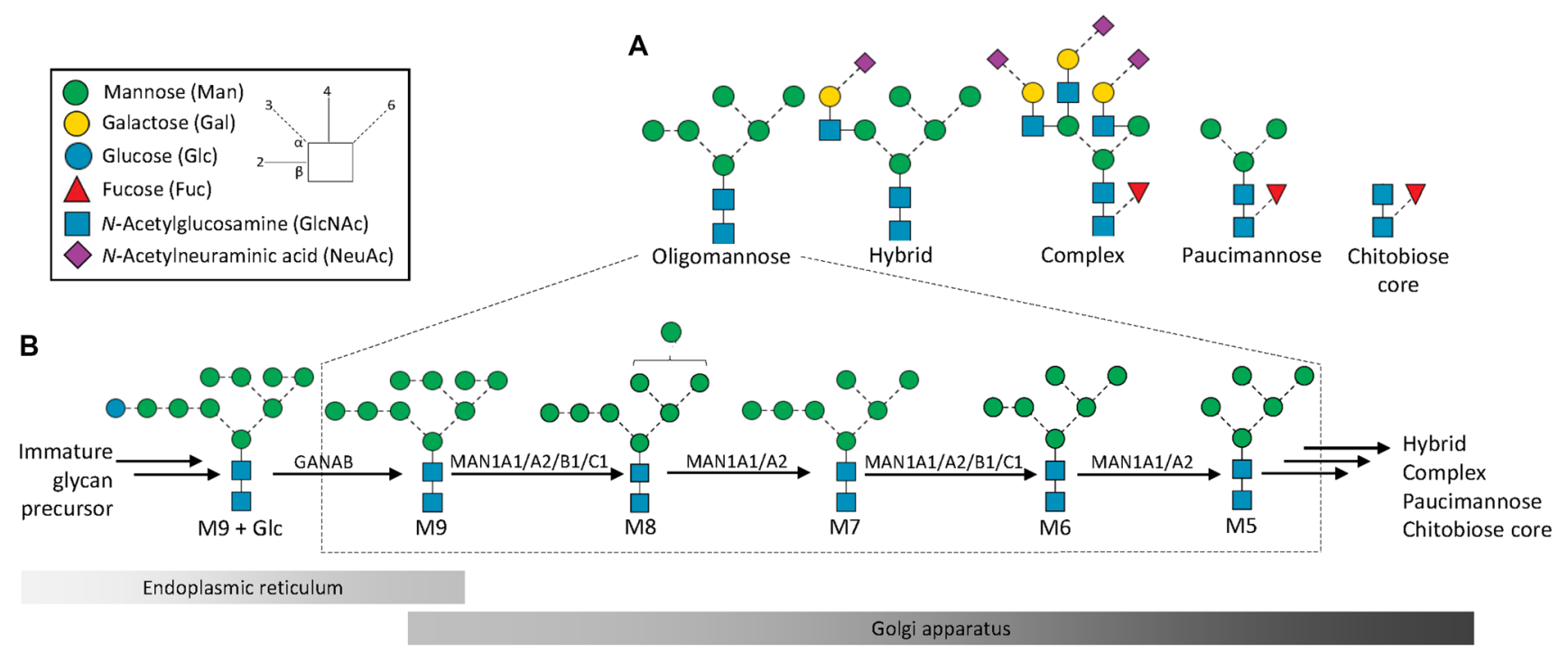

Figure 1: Structures, nomenclature and biosynthesis of protein oligomannosylation. (A) Oligomannose, one of five $N$-glycan types in human glycobiology, remains poorly studied in cancer research despite forming a large and vital part of the $N$-glycome. (B) Oligomannosidic $N$-glycans are formed via sequential enzymatic processing early in the biosynthetic pathway from immature Glc-capped glycan precursors in the endoplasmic reticulum (ER). The GANAB-mediated trimming of M9+Glc to M9 is followed by the processing by multiple ER- and Golgi-resident a1,2-mannosidases (MAN1A1, MAN1A2, MAN1B1, and MAN1C1) that successively trim M9 to M5. Each of the oligomannosidic glycans is known to exist as multiple isomers; only the most common isomeric form is depicted in this figure, see Supplementary Data 1 and Figure 3C for complete overview of observed isomers. The glycan processing may in cancer cells and in other cell types terminate during the oligomannose trimming reactions or continue to form more processed $N$-glycan types generating an extensive micro-heterogeneity typically observed for glycoproteins. Insert: key to monosaccharide symbols and glycosidic linkages [1]. 
in brain (glioblastoma and neuroblastoma), blood (acute lymphocytic leukemia, ALL; acute monocytic leukemia, AML; acute promyelocytic leukemia, APL; chronic lymphocytic leukemia, CLL), bladder (BlaCa), melanoma and non-melanoma (basal cell carcinoma, BCC and squamous cell carcinoma, SCC) skin, breast (BC), hepatocellular carcinoma (HCC, liver), lung, ovarian $(\mathrm{OvC})$, gastric $(\mathrm{GC})$, colorectal (CRC) and prostate cancer (PCa) [38]. These findings were supported by quantitative glycomics data from nearly 500 porous graphitized carbon (PGC) LC-MS/MS datasets acquired over 10 years across laboratories around the world from a variety of cancer specimens including cultured human cancer cells and tissues from cancer patients and matching controls using a uniform analytical platform. The paucimannosidic-centric study, however, did not explore the wealth of other valuable information, including the oligomannosidic signatures, found in this compilation of content-rich $N$-glycomics datasets.

Guided by an initial literature survey suggesting that associations exist between oligomannosylation and human cancers, we have herein reinterrogated our unique collection of $N$-glycomics datasets to systematically test for oligomannose-cancer relationships across a variety of human cancer types. It transpires from this meta-analysis and supporting evidence from newly acquired matrixassisted laser desorption/ionization mass spectrometry imaging (MALDI-MSI) and lectin flow cytometry data and enzyme expression data retrieved from well-curated cancer repositories that oligomannosylation and $\alpha 1,2$ mannosidase expression are significantly modulated in many types of human cancers.

\section{RESULTS AND DISCUSSION}

\section{Literature suggests oligomannose-cancer associations}

Despite forming a large and vital part of the human $N$-glycome, the role(s) of oligomannosylation in cancer remains poorly studied. To this end, we firstly performed a comprehensive and unbiased survey of the original research literature published over the past two decades in the field of glyco-oncology to test for a possible link between oligomannosylation and human cancers. Interestingly, we identified a considerable body of research papers that consistently reported on oligomannose elevation across 10 cancer types including bladder (BlaCa) [39], breast (BC) [40], cholangiocarcinoma (CC) [41], colorectal (CRC) [36], endometrial [42], liposarcoma [43], lung [44], ovarian (OvC) [45], oral cancer (OC) [46], and prostate cancer (PCa) [47], Table 1. These scattered but consistent observations reported by various research groups around the world were made from a diverse set of cancer specimens (cell lines, tissues and bodily fluids) using different analytical techniques (MS, HPLC, and lectin arrays). Importantly, the cancer-associated elevation of oligomannose was supported by multiple independent studies for several cancer types. Notably, we also found papers describing unchanged or reduced levels of oligomannosylation in five other cancer types including gastric (GC) [48], hepatocellular carcinoma (HCC) [49], kidney (KC) [50], pancreas (PanCa) [51], and thyroid cancer (TC) [52]. Thus, our initial literature survey indicated that interesting associations exist between oligomannosidic $N$-glycans and a subset of human cancers.

\section{Reinterrogation of pan-cancer LC-MS/MS glycomics datasets}

Guided by the literature survey, we then revisited our collection of 467 PGC-LC-MS/MS glycomics datasets previously compiled for a recent pan-cancer study [38] to systematically test for associations between oligomannosylation and cancer. Our quantitative glycome datasets covered 11 types of human cancers including brain (glio- and neuroblastoma), BlaCa, blood (APL, AML, ALL), skin (melanoma and non-melanoma, BCC and $\mathrm{SCC}$ ), BC, lung, $\mathrm{HCC}, \mathrm{GC}, \mathrm{CRC}, \mathrm{PCa}$ and $\mathrm{OvC}$ spanning both an extensive set of human cell lines and cohorts of paired and unpaired tumour/non-tumour tissue samples. Importantly, all $N$-glycome datasets were acquired using the same analytical technique enabling not only relative $N$-glycan quantitation within each sample, but also accurate comparisons within and between sample cohorts.

The five common oligomannosidic $N$-glycans, M5M9 (depicted in Figure 1), were consistently identified and quantified across all samples. As expected from the biosynthetic trimming process, isomers of the oligomannosidic $N$-glycans were identified across most samples. The less common M4, M8 + Glc and M9+ Glc were observed at low abundance in some samples and left out of the quantitation of the oligomannosidic glycan series. The spectral evidence for the reported structures can be found in Supplementary Data 1 and all $N$-glycome profile data are available in Supplementary Data 2 and 3.

\section{Cell line glycoprofiling demonstrates that oligomannose is a cancer-wide but highly variable signature}

Our glycomics data of 34 human cell lines spanning 9 cancer types showed that oligomannosidic $N$-glycans are universally expressed in all cancerous cells, but span a wide abundance range, Supplementary Tables 1 and 2 . While the total oligomannose levels varied considerably across the investigated cancer types and between the protein fractions (5.3-84.3\% of the $N$-glycome), the whole cell lysate and microsomal fractions were consistently rich in oligomannose $(>20 \%)$, Figure 2A and Supplementary Table 6. In line with our previous observation [69], less oligomannosylation was consistently found in 
Table 1: Literature survey exploring a possible link between oligomannose and human cancers

\begin{tabular}{|c|c|c|c|c|}
\hline Cancer type & Biological samples $(n)$ & Oligomannose levels & $\begin{array}{l}\text { Analytical method(s) } \\
\text { i) analyte, ii) method }\end{array}$ & Ref \\
\hline \multicolumn{5}{|c|}{ Literature indicating oligomannose elevation in human cancers } \\
\hline $\begin{array}{l}\text { Bladder } \\
\text { cancer }(\mathrm{BlaCa})\end{array}$ & $\begin{array}{l}\text { Five BlaCa cell lines: } \\
\text { a) KK47, YTS1, J82, T24 (cancer) } \\
\text { b) HCV29 (non-cancer) }\end{array}$ & $\begin{array}{l}\text { M5-M9 were elevated in BlaCa } \\
\text { cell lines }\end{array}$ & $\begin{array}{l}\text { i) Amidated } N \text {-glycans } \\
\text { ii) MALDI-TOF/TOF-MS }\end{array}$ & [39] \\
\hline \multirow[t]{4}{*}{$\begin{array}{l}\text { Breast } \\
\text { cancer }(\mathrm{BC})\end{array}$} & $\begin{array}{l}\text { a) Eight BC cell lines: SK-BR-3, MCF-7, } \\
\text { MDA-MB-231, T-47D, ZR-75-30, Bcap37, } \\
\text { Hs-578T (cancer) and MCF-10A (non-cancer) } \\
\text { b) Paired BC patient tumour vs adjacent non- } \\
\text { tumour tissues (100) }\end{array}$ & $\begin{array}{l}\text { M5-M9 were elevated, } \\
\text { particularly M8 level, in both BC } \\
\text { cell lines and tumour tissues }\end{array}$ & $\begin{array}{l}\text { i) Neuraminidase-treated APTS-labelled } \\
N \text {-glycans } \\
\text { ii) ABI-3130 sequencer (Single capillary } \\
\text { DNA sequencer) }\end{array}$ & {$[53]$} \\
\hline & $\begin{array}{l}\text { Sera from: } \\
\text { a) BC patients ( } 7 \text { ) } \\
\text { b) healthy donors (5) }\end{array}$ & $\begin{array}{l}\text { M5-M9 were elevated in sera } \\
\text { from BC patients }\end{array}$ & $\begin{array}{l}\text { i) Non-derivatized } N \text {-glycans } \\
\text { ii) MALDI FT-ICR-MS and HPLC-Chip- } \\
\text { TOF-MS }\end{array}$ & {$[40]$} \\
\hline & $\begin{array}{l}\text { a) Five BC cell lines: MCF-7, BT-474, SKBR-3, } \\
\text { MDA-MB-231 (cancer) and MCF-10A (non- } \\
\text { cancer) } \\
\text { b) Paired BC patient tumour vs adjacent non- } \\
\text { tumour tissues ( } 86 \text { ) }\end{array}$ & $\begin{array}{l}\text { M5-M9 were elevated in both BC } \\
\text { cell lines and tumour tissues }\end{array}$ & $\begin{array}{l}\text { i) 2-AB-labeled } N \text {-glycans } \\
\text { ii) PGC-LC-ESI-CID-MS/MS }\end{array}$ & [54] \\
\hline & $\begin{array}{l}\text { Seven BC cell lines: } \\
\text { a) MDA-MB-435, MDA-MB-231, 578T, BT- } \\
549, \mathrm{NCI} / \mathrm{ADR}-\mathrm{RES}, \mathrm{T}-47 \mathrm{D} \text { (cancer) } \\
\text { b) MCF-10A (non-cancer) }\end{array}$ & $\begin{array}{l}\text { M5-M9 were elevated, } \\
\text { particularly M5-M6 levels, in } \\
\text { both invasive and non-invasive } \\
\text { BC cell lines }\end{array}$ & $\begin{array}{l}\text { i) Permethylated } N \text {-glycans } \\
\text { ii) MALDI-TOF/TOF-MS }\end{array}$ & [55] \\
\hline \multirow[t]{2}{*}{$\begin{array}{l}\text { Cholangiocarcinoma } \\
\text { (CC, bile duct } \\
\text { cancer) }\end{array}$} & $\begin{array}{l}\text { Four CC cell lines: } \\
\text { a) KKU2-213AL5/BL5 (metastatic) } \\
\text { b) KKU-213A/B (parental) }\end{array}$ & $\begin{array}{l}\text { M5-M9 were elevated in } \\
\text { metastatic CC cell lines }\end{array}$ & $\begin{array}{l}\text { i) Non-derivatized } N \text {-glycans and } \\
N \text {-glycopeptides } \\
\text { ii) nano-LC-ESI-QTOF-CID-MS/MS and } \\
\text { RP-LC QE Plus-Orbitrap-HCD-MS/MS }\end{array}$ & [41] \\
\hline & $\begin{array}{l}\text { Sera from: } \\
\text { a) CC patients (8) } \\
\text { b) healthy donors (4) }\end{array}$ & $\begin{array}{l}\text { M6 was elevated (M7-M9 } \\
\text { reduced) in sera from CC patients }\end{array}$ & $\begin{array}{l}\text { i) Permethylated } N \text {-glycans } \\
\text { ii) Infusion on LTQ-ESI-CID-MS/MS }\end{array}$ & {$[56]$} \\
\hline \multirow[t]{4}{*}{$\begin{array}{l}\text { Colorectal cancer } \\
(\mathrm{CRC})\end{array}$} & $\begin{array}{l}\text { Paired FFPE tissue from CRC patient tumour vs } \\
\text { adjacent non-tumour tissues (16) }\end{array}$ & $\begin{array}{l}\text { M5-M9 were elevated in CRC } \\
\text { tumour tissues }\end{array}$ & $\begin{array}{l}\text { i) Amidated } N \text {-glycans } \\
\text { ii) MALDI-TOF/TOF-MS }\end{array}$ & {$[57]$} \\
\hline & $\begin{array}{l}\text { Unpaired FFPE tissues from: } \\
\text { a) CRC patients (stages I-IV, 18) } \\
\text { b) healthy donors (5) }\end{array}$ & $\begin{array}{l}\text { M5-M9 were elevated in } \\
\text { advanced (stage III-IV) CRC } \\
\text { tumour tissues }\end{array}$ & $\begin{array}{l}\text { i) Non-derivatized } N \text {-glycans } \\
\text { ii) MALDI-TOF/TOF-MS }\end{array}$ & [58] \\
\hline & $\begin{array}{l}\text { Paired CRC patient tumour vs adjacent non- } \\
\text { tumour tissues ( } 43 \text { ) }\end{array}$ & $\begin{array}{l}\text { M5-M9 were elevated in CRC } \\
\text { tumour tissues }\end{array}$ & $\begin{array}{l}\text { i) Permethylated } N \text {-glycans } \\
\text { ii) PGC-LC-ESI-CID-MS/MS }\end{array}$ & [59] \\
\hline & $\begin{array}{l}\text { a) Unpaired tissues from: CRC patients (stages } \\
\text { II-III, 15) and healthy donors (15) } \\
\text { b) Unpaired sera from: CRC patients (11) and } \\
\text { healthy donors (11) }\end{array}$ & $\begin{array}{l}\text { M5-M9 were elevated, } \\
\text { particularly M7 level, in advanced } \\
\text { CRC tumour tissues }\end{array}$ & $\begin{array}{l}\text { i) Permethylated } N \text {-glycans } \\
\text { ii) MALDI-TOF-MS and RP-LC-ESI-CID- } \\
\text { MS/MS }\end{array}$ & {$[60]$} \\
\hline $\begin{array}{l}\text { Endometrial cancer } \\
\text { (uterine cancer) }\end{array}$ & $\begin{array}{l}\text { a) Paired FFPE tissues from patients (6) } \\
\text { b) Unpaired TMA from patients with ( } 8 \text { ) and } \\
\text { without (20) lymph node metastasis }\end{array}$ & $\begin{array}{l}\text { M6-M9 were elevated in tumour } \\
\text { tissues (similar M5 distribution in } \\
\text { tumour and non-tumour regions) }\end{array}$ & $\begin{array}{l}\text { i) Non-derivatized } N \text {-glycans } \\
\text { ii) MALDI-TOF/TOF-MS and PGC-LC- } \\
\text { ESI-CID-MS/MS }\end{array}$ & [42] \\
\hline $\begin{array}{l}\text { Liposarcoma } \\
\text { (fat cancer) }\end{array}$ & $\begin{array}{l}\text { a) Paired FFPE tissues from patients (32) } \\
\text { b) Unpaired TMA from patients (141) and } \\
\text { healthy donors (6) }\end{array}$ & $\begin{array}{l}\text { M6-M8 were elevated in tumour } \\
\text { tissues }\end{array}$ & $\begin{array}{l}\text { i) Non-derivatized } N \text {-glycans } \\
\text { ii) MALDI-TOF/TOF-MS }\end{array}$ & [43] \\
\hline \multirow[t]{3}{*}{$\begin{array}{l}\text { Lung } \\
\text { cancer }\end{array}$} & $\begin{array}{l}\text { Paired patient tumour vs adjacent non-tumour } \\
\text { tissues }(42)\end{array}$ & $\begin{array}{l}\text { M5-M9 were elevated in tumour } \\
\text { tissues }\end{array}$ & $\begin{array}{l}\text { i) Non-derivatized } N \text {-glycans } \\
\text { ii) Nano HPLC-Chip-TOF-MS }\end{array}$ & [44] \\
\hline & $\begin{array}{l}\text { Unpaired FFPE tissues from: } \\
\text { a) patients with peritumoral (24) and advanced } \\
\text { tumour (29) } \\
\text { b) healthy donors (14) }\end{array}$ & $\begin{array}{l}\text { M5-M9 were elevated in tumour } \\
\text { tissues }\end{array}$ & $\begin{array}{l}\text { i) Permethylated } N \text {-glycans } \\
\text { ii) MALDI-TOF/TOF-MS }\end{array}$ & {$[61]$} \\
\hline & $\begin{array}{l}\text { Sera from: } \\
\text { a) patients (64) } \\
\text { b) healthy donors (12) }\end{array}$ & $\begin{array}{l}\text { M5-M9 were elevated in sera } \\
\text { from patients }\end{array}$ & $\begin{array}{l}\text { i) Fluorescently labelled } N \text {-glycans } \\
\text { ii) Lectin microarray analysis }\end{array}$ & [62] \\
\hline \multirow[t]{3}{*}{$\begin{array}{l}\text { Ovarian } \\
\text { cancer } \\
(\mathrm{OvC})\end{array}$} & $\begin{array}{l}\text { Unpaired tissue samples from: } \\
\text { a) OvC patient ( } 83 \text { ) } \\
\text { b) healthy donors ( } 23)\end{array}$ & $\begin{array}{l}\text { M5-M9 were elevated in } \mathrm{OvC} \\
\text { tumour tissues }\end{array}$ & $\begin{array}{l}\text { i) Non-derivatized } N \text {-glycopeptides } \\
\text { ii) QE Orbitrap-HCD-MS/MS }\end{array}$ & [63] \\
\hline & $\begin{array}{l}\text { FFPE OvC tissues from advanced serous OvC } \\
\text { patients (3) }\end{array}$ & $\begin{array}{l}\text { M5-M9 were elevated in } \mathrm{OvC} \\
\text { tumour tissues }\end{array}$ & $\begin{array}{l}\text { i) Non-derivatized } N \text {-glycans were } \\
\text { detected using } \\
\text { ii) MALDI-TOF/TOF-MS }\end{array}$ & [64] \\
\hline & $\begin{array}{l}\text { Unpaired FFPE OvC tissues and TMA from: } \\
\text { a) early stage ( } 3 \text { ) } \\
\text { b) late stage (3) }\end{array}$ & $\begin{array}{l}\text { M5-M9 were elevated in } \\
\text { advanced OvC tumour tissues }\end{array}$ & $\begin{array}{l}\text { i) Non-derivatized } N \text {-glycans } \\
\text { ii) MALDI-TOF/TOF-MS and PGC-LC- } \\
\text { ESI-CID-MS/MS }\end{array}$ & [45] \\
\hline
\end{tabular}




\begin{tabular}{|c|c|c|c|c|}
\hline $\begin{array}{l}\text { Oral cancer } \\
(\mathrm{OC})\end{array}$ & $\begin{array}{l}\text { a) Three OC cell lines: OC2 (cancer), HOK and } \\
\text { SG (non-cancer) } \\
\text { b) Unpaired FFPE tissues from patients }(80) \text { and } \\
\text { healthy donors }(8)\end{array}$ & $\begin{array}{l}\text { M5-M9 were elevated in both } \\
\text { cancerous cell lines and tumour } \\
\text { tissues }\end{array}$ & $\begin{array}{l}\text { i) Permethylated } N \text {-glycans } \\
\text { ii) MALDI-TOF-MS }\end{array}$ & {$[46]$} \\
\hline \multirow[t]{3}{*}{$\begin{array}{l}\text { Prostate cancer } \\
(\mathrm{PCa})\end{array}$} & $\begin{array}{l}\text { Sera from PCa patients with different stages: } \\
\text { a) indolent (41) } \\
\text { b) significant (32) } \\
\text { c) aggressive (44) }\end{array}$ & $\begin{array}{l}\text { M5-M9 were elevated, } \\
\text { particularly, M8 level, in sera } \\
\text { from advanced-stage PCa patients }\end{array}$ & $\begin{array}{l}\text { i) 2-AB-labelled } N \text {-glycans } \\
\text { ii) HILIC-UPLC with fluorescence detector }\end{array}$ & [47] \\
\hline & De-identified PCa FFPE tissue block & $\begin{array}{l}\text { M5-M9 were elevated in } \mathrm{PCa} \\
\text { tumour region }\end{array}$ & $\begin{array}{l}\text { i) Non-derivatized } N \text {-glycans } \\
\text { ii) MALDI FT-ICR-MS }\end{array}$ & {$[65]$} \\
\hline & $\begin{array}{l}\text { Sera from: } \\
\text { a) PCa patients with grade } 3(84) \text { and grade } 4 / 5 \\
(204) \\
\text { b) healthy donors (135) }\end{array}$ & $\begin{array}{l}\text { M9 was elevated in advanced } \\
\text { stages of sera from PCa patients } \\
\text { (M5-M8 were not analyzed) }\end{array}$ & $\begin{array}{l}\text { i) Anti-oligomannose antibodies } \\
\text { ii) Carbohydrate microarrays and antigen- } \\
\text { specific ELISA assays }\end{array}$ & {$[66]$} \\
\hline \multicolumn{5}{|c|}{ Literature indicating reduced/unchanged oligomannose levels in cancers } \\
\hline $\begin{array}{l}\text { Gastric } \\
\text { cancer }(\mathrm{GC})\end{array}$ & $\begin{array}{l}\text { Sera from: } \\
\text { a) GC patients ( } 54) \\
\text { b) healthy donors (18) }\end{array}$ & $\begin{array}{l}\text { Decreased M5-M9 in sera from } \\
\text { GC patients }\end{array}$ & $\begin{array}{l}\text { i) Non-derivatized } N \text {-glycans } \\
\text { ii) MALDI FT-ICR-MS }\end{array}$ & {$[48]$} \\
\hline \multirow[t]{4}{*}{$\begin{array}{l}\text { Hepatocellular } \\
\text { carcinoma (HCC, } \\
\text { liver cancer) }\end{array}$} & $\begin{array}{l}\text { Paired HCC patient tumour vs adjacent non- } \\
\text { tumour tissues }(88)\end{array}$ & $\begin{array}{l}\text { Decreased M8 in HCC tissues } \\
\text { (M5-M7 were not analyzed, } \\
\text { and M9 co-eluted with another } \\
\text { analyte) }\end{array}$ & $\begin{array}{l}\text { i) Neuraminidase-treated APTS-labelled } \\
N \text {-glycans } \\
\text { ii) ABI-3130 sequencer (single capillary } \\
\text { DNA sequencer) }\end{array}$ & [49] \\
\hline & Paired FFPE HCC tissues from patients (2) & $\begin{array}{l}\text { Similar distribution of M8 in both } \\
\text { HCC patient tumour and adjacent } \\
\text { non-tumour tissues (M5-M7 and } \\
\text { M9 were analyzed but not } \\
\text { reported) }\end{array}$ & $\begin{array}{l}\text { i) Ethyl esterified } N \text {-glycans } \\
\text { ii) MALDI FT-ICR-MS }\end{array}$ & {$[67]$} \\
\hline & $\begin{array}{l}\text { Paired FFPE TMA from HCC patient tumour vs } \\
\text { adjacent non-tumour tissues (16) }\end{array}$ & $\begin{array}{l}\text { Decreased M8 in HCC tissues } \\
\text { (M5-M7 and M9 were analyzed } \\
\text { but not reported) }\end{array}$ & $\begin{array}{l}\text { i) Non-derivatized } N \text {-glycans } \\
\text { ii) MALDI FT-ICR-MS }\end{array}$ & [65] \\
\hline & $\begin{array}{l}\text { a) Paired whole HCC and normal tissue (1) } \\
\text { b) Unpaired FFPE TMA from HCC patient } \\
\text { tumours (with history of Hepatitis B virus, } 40 \text { ), } \\
\text { liver cirrhosis (22) and non-tumour tissues (5) }\end{array}$ & $\begin{array}{l}\text { Similar distribution of M5-M9 in } \\
\text { non-tumour, cirrhotic and HCC } \\
\text { tissues }\end{array}$ & $\begin{array}{l}\text { i) Non-derivatized } N \text {-glycans } \\
\text { ii) MALDI FT-ICR-MS }\end{array}$ & {$[68]$} \\
\hline $\begin{array}{l}\text { Kidney } \\
\text { cancer } \\
(\mathrm{KC})\end{array}$ & $\begin{array}{l}\text { Paired FFPE TMA from KC stages I-IV patient } \\
\text { tumour vs adjacent non-tumour tissues }(\sim 150)\end{array}$ & $\begin{array}{l}\text { M5-M9 mainly detected in non- } \\
\text { tumour regions, but also present } \\
\text { in tumour regions }\end{array}$ & $\begin{array}{l}\text { i) Non-derivatized } N \text {-glycans } \\
\text { ii) MALDI FT-ICR-MS and MALDI-TOF/ } \\
\text { TOF-MS }\end{array}$ & {$[50]$} \\
\hline \multirow[t]{2}{*}{$\begin{array}{l}\text { Pancreas cancer } \\
(\mathrm{PanCa})\end{array}$} & $\begin{array}{l}\text { Paired FFPE TMA PanCa patient tumour vs } \\
\text { adjacent non-tumour tissues }(53)\end{array}$ & $\begin{array}{l}\text { M5-M9 mainly detected in non- } \\
\text { tumour regions, but also present } \\
\text { in tumour regions }\end{array}$ & $\begin{array}{l}\text { i) Amidated } N \text {-glycans } \\
\text { ii) MALDI FT-ICR-MS and MALDI- } \\
\text { QTOF-MS }\end{array}$ & [51] \\
\hline & De-identified PanCa FFPE tissue block & $\begin{array}{l}\text { M5-M9 mainly detected in } \\
\text { non-tumour regions, but M8 is } \\
\text { elevated in tumour regions }\end{array}$ & $\begin{array}{l}\text { i) Non-derivatized } N \text {-glycans } \\
\text { ii) MALDI FT-ICR-MS }\end{array}$ & {$[65]$} \\
\hline $\begin{array}{l}\text { Thyroid cancer } \\
\text { (TC) }\end{array}$ & $\begin{array}{l}\text { Paired TC patient tumour vs adjacent non- } \\
\text { tumour tissues (23) }\end{array}$ & $\begin{array}{l}\text { Decreased M5-M9 in TC tumour } \\
\text { tissues }\end{array}$ & $\begin{array}{l}\text { i) Ethyl esterified } N \text {-glycans } \\
\text { ii) MALDI-TOF/TOF-MS }\end{array}$ & {$[52]$} \\
\hline
\end{tabular}

"All $N$-glycans were liberated from their carrier proteins using peptide: $N$-glycosidase F. Abbreviations: 2-AB: 2-aminobenzoic acid; APTS: 8-amino-1,3,6pyrenetrisulfonic acid; FFPE: formalin-fixed paraffin-embedded; TMA: tissue microarray.

the secretome of cultured cancer cells relative to the microsomal and whole cell lysate fractions indicating that oligomannosidic $N$-glycans are mainly features of the cellular component of cancer cells. The M5-M9 glycans were all common but highly variable oligomannosidic species expressed by the cancer cell lines, Figure 2B and Supplementary Table 7 . While these observations point to a significant glycan under-processing in cancer cells, incompletely processed glycoproteins still trafficking the ER and cis-Golgi of the secretory pathway may also contribute to the high levels of oligomannosylation detection in cancer cells. Glycan processing may be impacted by several cellular factors e.g., rate of protein synthesis, cellular growth rate (doubling time), protein trafficking time, and the levels of multiple glycanprocessing enzymes and nucleotide sugars [70] as well as various protein factors [71]. While the reduced expression of several $\alpha 1,2$-mannosidases catalyzing the M9-to-M5 trimming process has been reported in cancer (discussed below) [72-74], the possible contribution of these many other cellular and protein factors to the oligomannoserich glycophenotypes of cancer cells remains unexplored. Despite their relatively low secretion rate from cancers cells, oligomannosidic $N$-glycoproteins have repeatedly been found to be elevated in blood of cancer patients including those suffering from $\mathrm{BC}, \mathrm{CC}$ and lung cancers 
$[40,56,62]$ relative to the low levels of oligomannose found in the blood of healthy individuals $[75,76]$.

Comparative glycoprofiling of a few "normal" (non-tumourigenic) immortalized cell lines derived from breast (HMEC) and ovarian (HOSE 6.3 and HOSE 17.1) tissues and their matching cancerous cell lines from the same tissue origins including Hs-578T, MCF-7, MDAMB-157/231/468 and SK-BR-3 breast cancer cell lines and A2780, IGROV1 and SKOV3 ovarian cancer cell lines indicated an elevation of oligomannose in the cancer cell lines (data not shown), a relationship explored in greater details below using glycomics of paired tumour/ non-tumour tissue samples.

Cell surface glycoepitopes are known to play important roles in cell-cell and cell-extracellular matrix communication $[1,27,77]$. To this end, we explored the cell surface expression of oligomannosidic epitopes of the oligomannose-rich promyelocytic HL-60 cell line using lectin flow cytometry. Significant surface reactivity to the mannose-recognizing lectin, concanavalin A (ConA, FITC-conjugated) was observed, Figure 2C (green trace). Importantly, the ConA reactivity could be competitively inhibited by methyl- $\alpha$-D-mannopyranoside (Me- $\alpha-D-M a n)$ (purple trace) bringing the signal back to the base levels established for HL-60 without ConA-FITC treatment (grey trace). The putative cell surface expression of oligomannosidic epitopes on HL-60 cells and possibly other cancer cells is interesting as it suggests roles of oligomannose in cancer cell communication and may open for novel glycan-centric diagnostic approaches as well as new treatment strategies such as chimeric antigen receptor T-cell therapy directed to surfaceexposed oligomannose [78]. Supporting the cell surface expression of oligomannose, several mannose-recognizing receptors such as macrophage mannose receptor (CD206), DC-SIGN [79], langerin [80] and dectin-2 [81] have been found to recognize oligomannosidic $N$-glycans expressed on tumour cells [82]. The recent development of a comprehensive oligomannose microarray may open for the identification of additional receptors recognizing oligomannose-decorated cancer cells and tissues [83].

\section{Comparative tissue glycomics and MALDI-MS imaging confirm oligomannose elevation in a subset of cancer types}

Next, $N$-glycomics data from 126 paired and unpaired tumour/non-tumour tissues (fresh frozen, FF and formalin-fixed paraffin-embedded, FFPE) from various patient cohorts spanning seven cancer types were reanalyzed, Supplementary Tables 3 and 4. A subset of the investigated cancer types including non-melanoma BCC (FF, $n=14$; FFPE, $n=20$ ) and SCC (FFPE, $n=15$ ), and CRC (FF, $n=5-6$ ) showed strong tumour-associated elevation of oligomannose $(p<0.0001$ for all three cancer types, paired two-tailed $t$-tests), Figure 3A. Most of the individual oligomannosidic $N$-glycan species showed a significant elevation in the tumour tissues relative to the

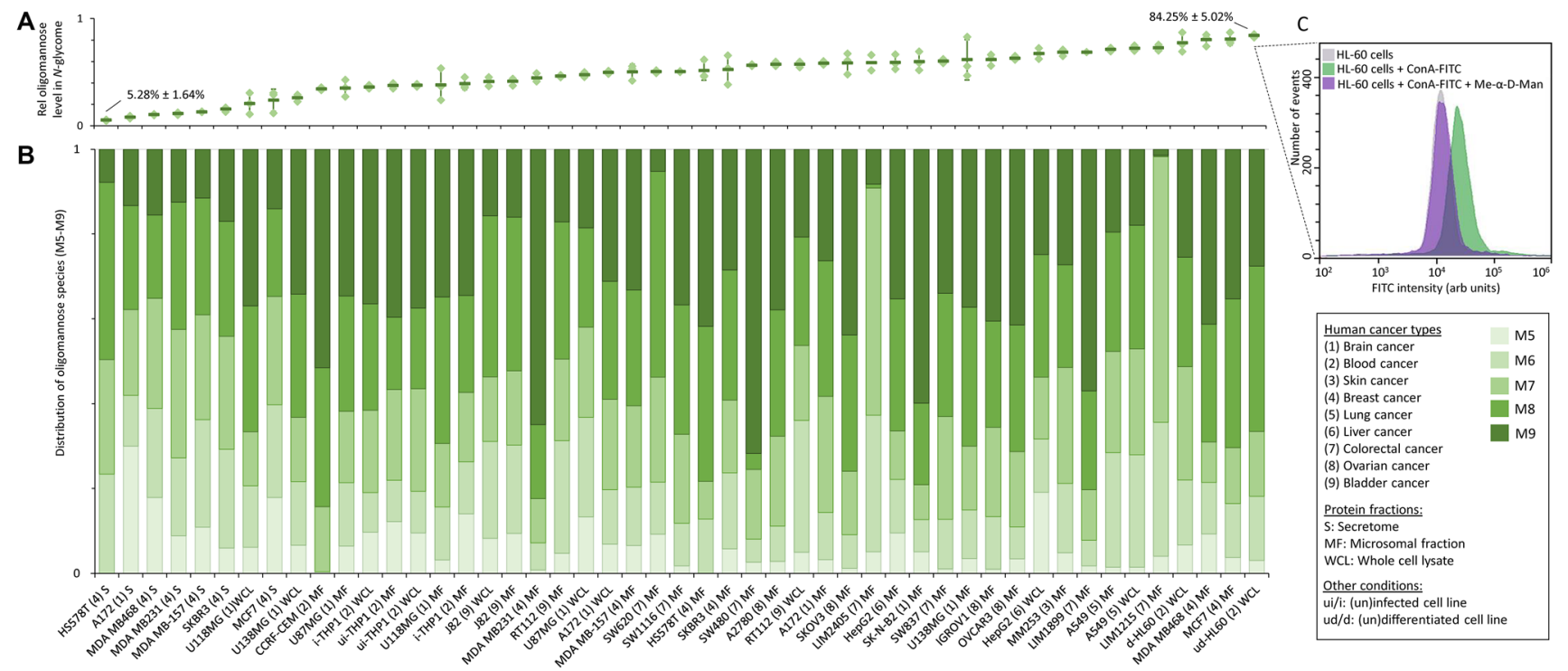

Figure 2: Oligomannose content across human cancer cell lines. (A) Total oligomannose level and (B) the relative distribution of individual oligomannosidic species (M5-M9) of the $N$-glycome from different protein fractions (secretome, microsomal fractions, whole cell lysates) of all investigated 34 human cancer cell lines spanning nine cancer types. See Supplementary Tables 1 and 2 for details of the studied cell lines. For A and B, data were either plotted as the mean $\pm \mathrm{SD}$ (for $n \geq 3$, technical replicates) or as the mean (for $n=2$, technical duplicates). See Supplementary Data 2 and Supplementary Tables 6 and 7 for raw and tabulated quantitative glycome data, respectively. (C) Cell surface expression of oligomannosidic epitopes of the oligomannose-rich HL-60 cell line was shown by a surface reactivity of the mannose-recognizing concanavalin A (ConA, FITC-conjugated, green trace) using lectin flow cytometry. The ConA reactivity could be competitively inhibited by methyl- $\alpha$-D-mannopyranoside (Me- $\alpha$-D-Man) (purple trace) bringing the signal to background HL-60 levels as established without ConA-FITC treatment (grey trace). 
adjacent control tissues albeit no consistent patterns of the relative M5-M9 distribution between the studied cohorts and cancer types could be identified.

MALDI-MSI of glycans, a powerful tool to spatially profile liberated glycans from biological specimens including TMAs (as used here, see Supplementary Table 5 for meta-data) $[64,84,85]$, recapitulated the quantitative glycomics data by consistently showing a higher expression of specific oligomannosidic $N$-glycans in the tumour relative to non-tumourigenic tissues in $\mathrm{BCC}, \mathrm{SCC}$ and CRC, Figure 3B.

The tumour tissue PGC-LC-MS/MS data revealed as expected the presence of various isomers (M5a, M5b, M6a, M6b, M7a, M7b, M8a, M8b and M9) of the oligomannosidic species, Figure 3C. The quantitative profiling of each oligomannosidic isomer provided another level of structural insight into the regulation of the oligomannosidic $N$-glycans in BCC, SCC and CRC, Figure 3D.

In keeping with the observations made from our literature survey, our quantitative glycomics and MALDIMSI data supported that several cancer types showed unchanged or slightly reduced levels of oligomannose in tumour tissues relative to matching non-tumour tissues including HCC (FFPE, $n=3)$ and GC (FF, $n=3)(p \geq$ 0.05 for all cancer types, paired two-tailed $t$-tests) and PCa (FF, $n=5$ and 55) ( $p \geq 0.05$, unpaired two-tailed $t$-tests), Supplementary Figure 1 . While late-stage CLL also did not show oligomannose elevation relative to early-stage disease (FF, $n=4)$ ( $p \geq 0.05$, unpaired twotailed $t$-tests), all CLL tissues notably displayed very high levels of oligomannosylation $(>60 \%)$. Our data therefore did not point to a progression-dependent elevation of oligomannose in CLL, but follow-up analysis of B cells
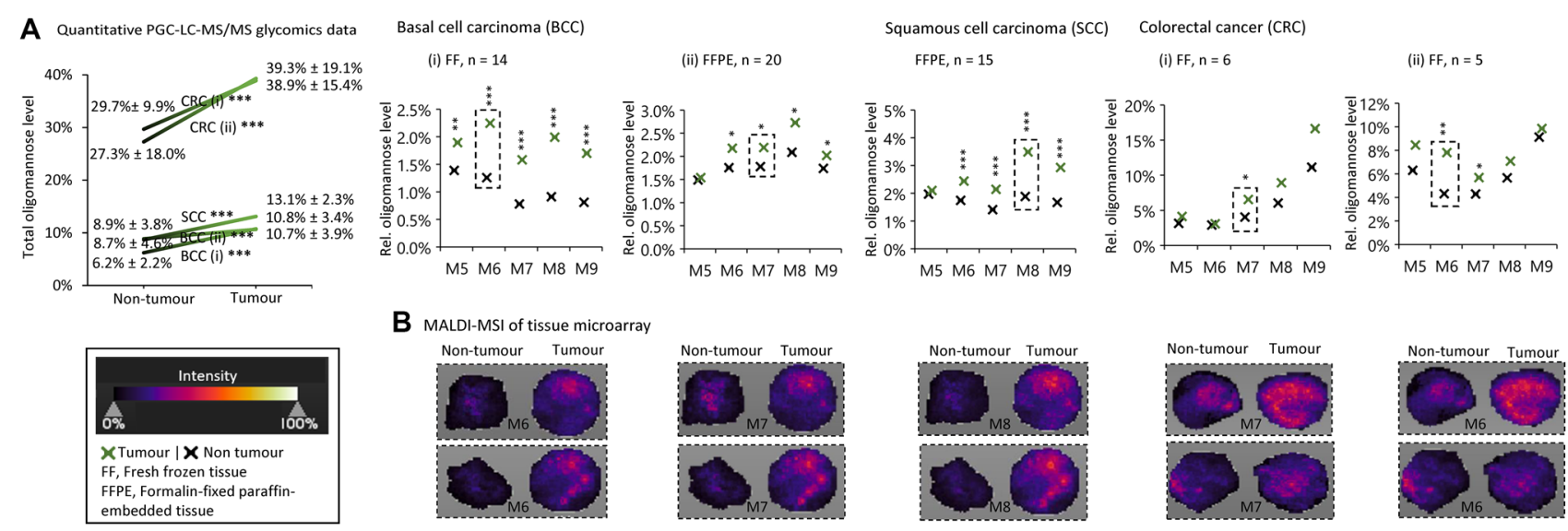

B MALDI-MSI of tissue microarray
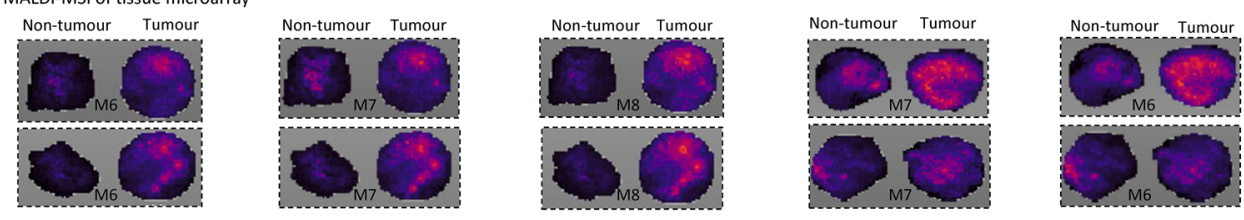

C Overview of detected oligomannosidic isomers

D Quantitative profile of oligomannosidic isomers
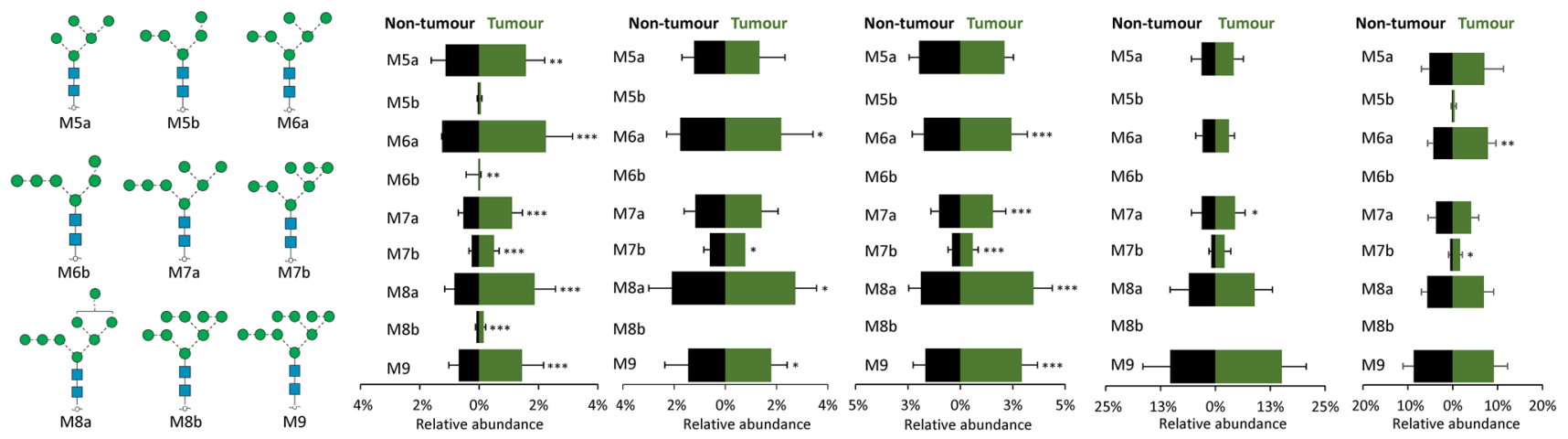

Figure 3: Tissue glycomics and MALDI-MSI data show oligomannose elevation in a subset of cancers. (A) Some cancer types displayed elevated oligomannose levels as demonstrated by quantitative glycomics of donor-paired tumour and non-tumour tissues from patients with basal cell carcinoma (BCC, i, FF; ii, FFPE tissues), squamous cell carcinoma (SCC) and colorectal cancer (CRC, i-ii, FF tissues). See Supplementary Tables 3 and 4 for details of the investigated tissues. See Supplementary Data 3 and Supplementary Table 8 and 9 for all raw and tabulated glycome data, respectively. Statistics was performed using paired and unpaired two-tailed $t$-tests $(n$, patient samples, as indicated). ${ }^{*} p<0.05,{ }^{* *} p<0.001,{ }^{* * *} p<0.0001$, n.s. not significant $(p \geq 0.05)$. (B) The MALDI-MSI data were from a TMA slide of unpaired tumour and non-tumour tissues. Representative examples of oligomannosidic $N$-glycans displaying prominent regulation in the tumour tissues have been provided (boxed, broken line). See key for MALDI-MSI intensity range and Supplementary Table 5 for details of the TMA used for the MALDI-MSI. (C) Overview of the oligomannosidic isomers detected from the PGC-LC-MS/MS glycomics experiments. (D) Quantitative profile of the detected oligomannosidic isomers from donor-paired tumour and non-tumour tissues of the same cancer types and samples explored in (A). Statistics was performed using paired two-tailed $t$-tests (n, patient samples, as indicated). ${ }^{*} p<0.05,{ }^{* *} p<0.001,{ }^{* * *} p<0.0001$, n.s. not significant $(p \geq 0.05)$. 
from healthy donors are still required to determine if raised oligomannose is a disease characteristic of CLL.

H\&E staining confirmed that the investigated spots were indeed from tumour and non-tumour regions across the TMA, Supplementary Figure 2A. The complete set of MALDI-MSI data depicting the spatial distribution and relative abundance of all the oligomannosidic species in the tumour and non-tumour tissues investigated in this study is provided in Supplementary Figure 2B. While this study did not address the cellular origin(s) of the elevated oligomannose in the heterogeneous tumour micro-environment (discussed below), MALDI-MSI and glycoproteomics with cell annotation of ovarian [45] and prostate $[65,86]$ tumour tissues have previously indicated that oligomannose-rich glycophenotypes are prominent features of cancer cells as oppose to the stroma, immune cells and other cell types forming important auxiliary components of the tumour microenvironment.

Collectively, these studies therefore indicate that raised oligomannose levels originate directly from the cancer cells, however, this aspect and the still elusive protein carriers of cancer-associated oligomannose require further investigation. Site-, protein- and even tissue-specific information, which can provide important mechanistic insight into the cancer-associated oligomannose elevation, can now be obtained with emerging glycoproteomics [86, 87] and advanced cellsorting and characterization technologies [88]. Sensitive and quantitative proteomics often performed in concert with glycoproteomics may also be able to profile the $\alpha 1,2$-mannosidases and other glycan-processing enzymes to inform more precisely on their regulation and hence support the link to altered oligomannosylation in cancer.

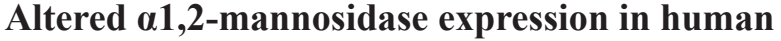 cancers}

We then investigated a possible connection between the biosynthetically relevant $\alpha 1,2$-mannosidases and oligomannose expression in cancer tissues. Using the Gene Expression Omnibus (GEO) database, the transcript (mRNA) expression of MAN1A1, MAN1A2, MAN1B1 and MAN1C1 measured from paired and unpaired tumour/non-tumour tissues were investigated, Figure 4 and Supplementary Data 4A. Mining the transcript data in the context of CRC and skin cancers for which our

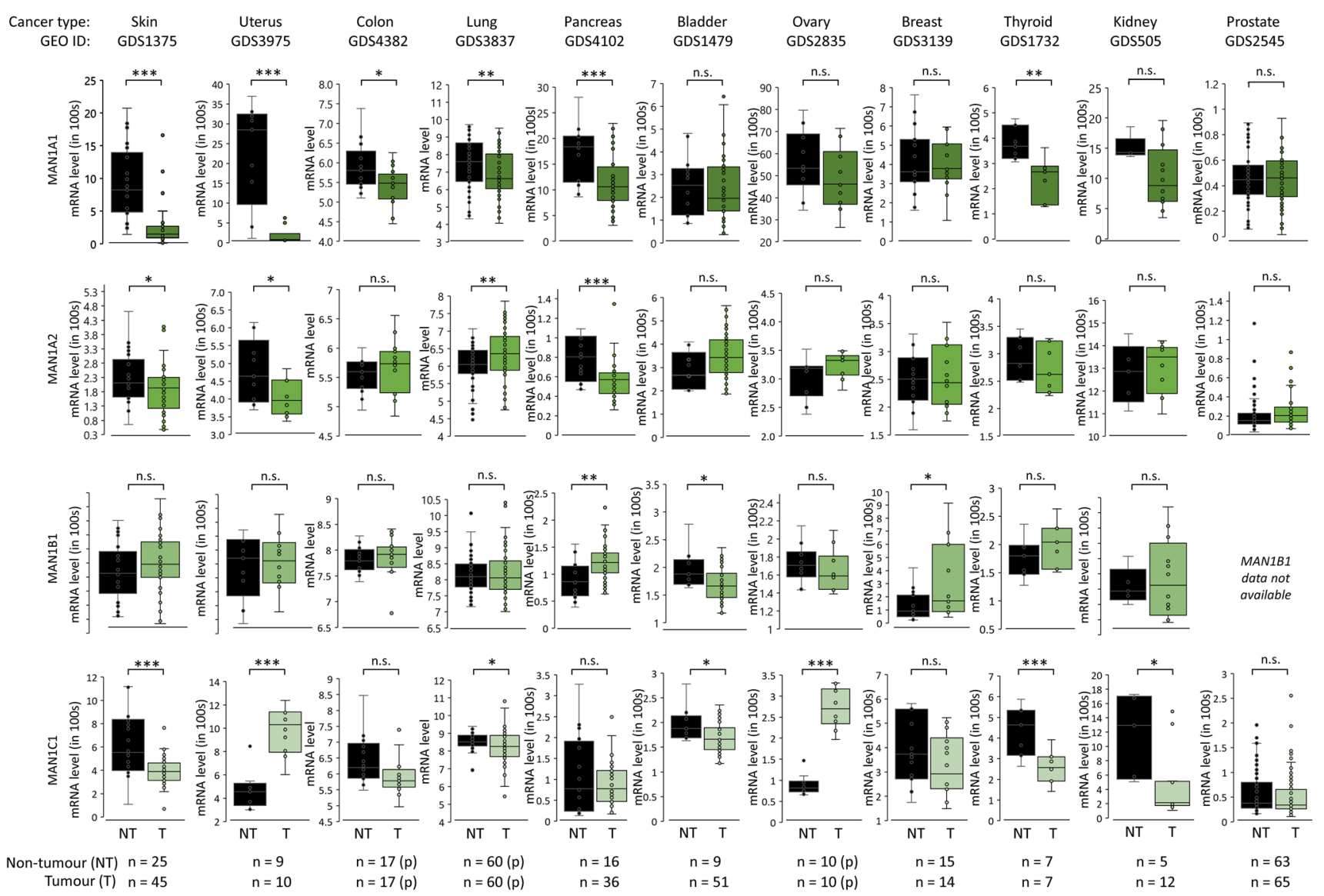

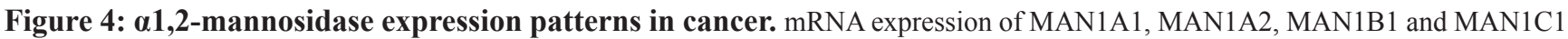
in paired (p) and unpaired tumour (different shading of green data points) and non-tumour (black data points) tissues across cancer types based on data extracted from the Gene Expression Omnibus (GEO). Statistics was performed using paired and unpaired two-tailed $t$-tests ( $n$, sample numbers, as indicated below the graphs). ${ }^{*} p<0.05,{ }^{* *} p<0.001,{ }^{* * *} p<0.0001$, n.s. not significant $(p \geq 0.05)$. 
glycomics data showed a cancer-associated elevation of oligomannosylation (see Figure 3), the expression analysis suggested a significant reduction in MAN1A1 in tumour compared to non-tumour tissues (both $p<0.05$ ). Further, MAN1A2 and MAN1C1 were also reduced in tumour relative to non-tumour tissues for skin cancer (both $p<$ 0.05 ). Albeit less consistent, trends of $\alpha 1,2$-mannosidase down-regulation were also observed for lung, bladder, and breast cancers that based on the literature survey also showed an elevation in oligomannosylation. While some cancer types with increased oligomannosylation such as uterine and ovarian cancers showed trends towards a decrease in MAN1A1 expression in tumour compared to non-tumour tissues, MAN1C1 interestingly showed the opposite pattern by being significantly elevated (both $p<0.0001$ ). Cancer types that showed no elevation in oligomannose (pancreatic, thyroid and kidney cancers) also displayed some degree of $\alpha 1,2$-mannosidase regulation suggesting that complex and yet-to-be-understood relationships exist between oligomannosylation and the processing enzymes in cancer.

We therefore sought to explore further the link between the a1,2-mannosidases and oligomannose expression in more simple biological systems. For this purpose, we compared transcript data of all four a1,2-mannosidases from five cancer cell lines (HL-60, CCRF-CEM, Hs-578T, SKOV3 and A549) retrieved from the Cell Miner ${ }^{\mathrm{TM}}$ database with our glycomics data from the same cell lines, Supplementary Figure 3A and Supplementary Data 4B. Correlation analyses showed that the oligomannose levels correlated negatively with the expression of MAN1A1 $(r=-0.809)$, MAN1A2 $(r$ $=-0.614)$ and MAN1B1 $(r=-0.966)$ while MAN1C1 showed a positive correlation $(r=+0.728)$. These observations support the complex interplay between the $\alpha 1,2$-mannosidases and the oligomannose levels in cancer.

To investigate whether the reduced expression of the a1,2-mannosidases observed in some cancers may be linked to high mutation rates of these enzymes, we explored the frequency of simple somatic mutations (SSMs) of the four $\alpha 1,2$-mannosidases across 11 cancer types (skin, uterus, colon, lung, gastric, bladder, ovary, breast, liver, kidney and prostate) using data retrieved from The Cancer Genome Atlas (TCGA), Supplementary Figure $3 \mathrm{~B}$ and Supplementary Data 4C. To enable comparisons across datasets, the cancer types were selected to match the cancers covered by our glycomics data and the literature survey. Interestingly, relatively high SSM rates of all four $\alpha 1,2$-mannosidases were found in cancer types displaying oligomannose elevation i.e., skin, uterus, colon, and lung cancers while lower $\alpha 1,2-$ mannosidase SSM rates were observed for liver, gastric, kidney and prostate cancers not featuring elevated oligomannosylation. Further investigations are required to determine how the SSMs impact the expression and activity of the $\alpha 1,2$-mannosidases.
While these observations based on publicly available expression datasets collectively point to the involvement of the $\alpha 1,2$-mannosidases in the cancerassociated elevation of oligomannose, attempts to relate more precisely the enzyme expression to the oligomannose levels observed across the different cancer types, did not reveal a clear and consistent pattern possibly highlighting the complex interplay between the four $\alpha 1,2$-mannosidases and oligomannose. For this study, we investigated three well established public repositories (GEO, Cell Miner ${ }^{\mathrm{TM}}$ and TCGA) all packed with valuable data and resources, but other public databases including Gene Expression Atlas [89], SAGEmap [90] and XenaBrowser [91] can be explored further to generate a more complete picture of the regulation of the $\alpha 1,2$-mannosidases in human cancers.

Interestingly, a recent study showed that genetic disruption of the a1,2-mannosidases in HEK293 cells resulted in oligomannose elevation [92]. While the single knockouts of MAN1A1 and MAN1A2 did not exhibit changes, the double knockout HEK293 cell line of these two prominent $\alpha 1,2$-mannosidases displayed a significant increase in oligomannose. Additionally, an abundance of M9M8 structures were found in the triple knockout of MAN1A1, MAN1A2 and MAN1B1. These observations carried out under controlled conditions not only confirm the involvement of the $\alpha 1,2$-mannosidases in oligomannose processing, but also support a negative correlation between specific $\alpha 1,2-$ mannosidases i.e., MAN1A1, MAN1A2 and MAN1B1 and oligomannose reported here (see Supplementary Figure 3A) and indicate that these glycan-processing enzymes are in part able to compensate for each other.

MAN1A1 has repeatedly been reported to be down-regulated in a variety of metastatic cancer cell lines including in $\mathrm{HCC}$ [93], $\mathrm{CC}$ [41], $\mathrm{OvC} \mathrm{[94]} \mathrm{and} \mathrm{PCa}$ [95] relative to their non-metastatic counterparts. Thus, it can be speculated that MAN1A1 and/or the resulting oligomannosidic $\mathrm{N}$-glycan products may contribute (directly or indirectly) to the aberrant growth and dissemination of some cancer types. Moreover, a recent study showed that reduced MAN1A1 expression and oligomannose elevation are features of advanced-stage $\mathrm{BC}$ tumour tissues with high tumour aggressiveness relative to early-stage $\mathrm{BC}$ tumour tissues and suggested that these glyco-phenotypic characteristics lead to impaired survival in BC patients [72].

We found comparably less literature linking the other biosynthetically relevant $\alpha 1,2$-mannosidases to cancer. In a recent study, MAN1B1 expression was reported to be up-regulated in $\mathrm{BlaCa}$ relative to normal tissues and was found to be a regulator of cell proliferation [74]. Other studies have indicated that MAN1C1 is a tumour suppressor in KC [73] and HCC [96]. Finally, low expression of MAN1C1 (and a concomitant upregulation of MAN1A1) was also reported in HCC (hepatitis B-positive) stage 1 relative to stage 2 and 3 further supporting that MAN1C1 plays roles in tumour suppression, whereas MAN1A1 was suggested to be an 
oncogene in hepatocarcinogenesis [96]. We did not find any literature on the role of MAN1A2 in cancer.

Collectively, our glycomics data, the existing glycooncology literature and enzyme expression data retrieved from public cancer repositories suggest that several a1,2-mannosidases impact oligomannose expression in complex and yet-to-be-fully understood ways in some types of human cancer.

\section{Limitations of this study}

This study reports trends in oligomannose levels and $\alpha 1,2$-mannosidase expression patterns across several cancer types. The communicated trends were backed by a considerable volume of robust PGC-LC-MS/MS glycomics data and public transcriptomics data and were supported by complementary experimental data and a body of peer-reviewed literature. While these observations contribute to a better understanding of oligomannose in cancer, further exploration is required to identify the mechanistic link between oligomannosylation and cancers and several limitations of the study should be pointed out.

The study identified molecular trends from a diverse set of data obtained from various clinical sources rather than from a single uniform and controlled experiment. The presented data therefore feature a relatively high degree of variability arising, in part, from the multiple cohorts of clinical samples studied. While age and gender have previously been reported to impact glycosylation [97] and therefore may be considered potential confounding factors for the glycomics data reported herein, we did not identify any impact from age and gender possibly due to the relatively small and heterogenous sample cohorts included in this study. Other factors that may contribute to glycome variation including the exact location of the sampled tumour and non-tumour tissues, the nature and extent of the immune cell infiltrate, the metastatic potential and the disease progression of the studied tumours, as well as the ethnicity and blood types of patients and donors were not controlled for in this study. Follow up studies performed on a larger and more homogenous cohort comprising appropriate controls including age- and gender-matched healthy donors and donors exhibiting inflammation and which appropriately correct for confounding factors are required to confirm and expand on the trends reported herein.

The cultured cancer cell lines also profiled with this study represent comparably more homogenous specimens. However, given the fact that the studied cell lines arise from different tissue origins, were generated with various immortalization procedures, featured undisclosed and possibly highly variable passage numbers, were grown under diverse culture conditions and were sampled using different methods to extract different protein fractions, the glycomics data from these experiments are expected to vary considerably and may therefore contribute to the large spread in oligomannosylation levels observed across the glycoprofiling data of the cancer cell lines.

Adding to the limitations of the biological samples studied, several technical limitations should be mentioned. The H\&E staining supporting the MALDI-MSI data (performed on the same spots) was limited to a small and in some cases incomplete or disintegrated tissue core from the TMA. We were therefore unable to accurately correlate the observed spatial changes in oligomannosylation with specific tumour and non-tumour regions of the studied tissue sections. Delineating more effectively the spatial distribution of glycans in tumour tissues using MALDIMSI, ideally performed on a higher number of replicates preferably from paired tumour and adjacent non-tumour tissues from the same patients from which glycomics data are also available, will provide a better understanding of which cells in the complex tumour microenvironment contribute to the elevation of oligomannose observed in some cancers.

For the lectin flow cytometry used to probe the cell surface oligomannosylation, concanavalin A is known to recognize not only mannosyl epitopes but also crossreact with other glycoepitopes including biantennary complex-type $N$-glycans and terminal glucose moieties [98]. While we showed that Me- $\alpha$-Man competitively reduced ConA reactivity, the cell surface expression of oligomannosidic epitopes should therefore be confirmed using other mannose-recognizing lectins (ideally performed with and without endoglycosidase $\mathrm{H}$ treatment and $\alpha$-Man competitors as appropriate controls) and/or using orthogonal methods including MS-based glycomics profiling after subcellular fractionation or cell surface capture or via lectin arrays [99] and should be studied more widely across other cancer cell lines to determine if cell surface expression of oligomannosylation is a general feature of cancer cells.

\section{MATERIALS AND METHODS}

\section{Literature survey}

The glycomics and glycobiology literature was comprehensively surveyed in attempts to test for a link between oligomannose and human cancer using the PubMed (https://pubmed.ncbi.nlm.nih.gov/) and Google Scholar (https://scholar.google.com.au/) search engines. Combinations of search keywords were employed including "high-mannose" (with/without hyphen), "extended mannose", "oligomannose", "human", "cancer" and "carcinoma". Other keywords including " $N$-glycan", "glycoprofiling", and " $N$-glycome profiling" were used to retrieve additional literature. All types of human cancers, biological samples, and experimental and analytical methods were considered in the literature search. Only original contemporary research papers published from 2000-2021 were considered. Key details and the main 
findings from these papers were included in Table 1 without any new or additional data reinterrogation. Relevant reviews and associated research papers were also surveyed to ensure that the existing literature was exhaustively covered by our search efforts.

\section{Reinterrogation of cancer $\mathrm{N}$-glycomics datasets}

The biological samples, sample handling and data acquisition methods used to generate the compilation of LC-MS/MS glycomics datasets reinterrogated with this study have been exhaustively described in Chatterjee et al., 2018 [38]. The details are also found in the Extended Experimental Methods in the Supplementary Information.

In short, the biological samples included cultured human cancerous and non-cancerous cell lines spanning 9 different cancer types including brain (glioblastoma and neuroblastoma), blood (APL, AML, ALL), melanoma, $\mathrm{BC}$, lung, HCC, CRC, OvC and BlaCa, Supplementary Tables 1 and 2, and tumour and adjacent control tissue samples from six different cancer types including blood (CLL), non-melanoma skin (BCC and SCC) cancer, GC, HCC, CRC and PCa, Supplementary Tables 3 and 4.

Proteins were extracted from the biological specimens, and the $N$-glycans released and handled as previously described $[100,101]$. Proteins from each cell line were extracted from either the secretome, microsomal fraction and/or whole cell lysate and spotted in technical triplicates for three separate rounds of $N$-glycan release and analysis except for the proteins extracted from the CRC cell lines that were spotted in technical duplicates. No technical replicates were performed for the tissue samples that instead were studied as biological replicates from different patients. In short, the $N$-glycans were liberated using peptide: $N$-glycosidase $\mathrm{F}$ and quantitatively profiled in their reduced but otherwise non-derivatized alditol form using PGC-LC-MS/MS in negative ion polarity using linear and $3 \mathrm{D}$ ion trap mass spectrometers.

The raw data of all 467 LC-MS/MS glycomics datasets (available via the MassIVE Consortium, ftp:// massive.ucsd.edu/MSV000083727/) were for the purpose of this study reinterrogated using the ESI-compass data analysis 4.0 software v1.1 (Bruker Daltonics) or Xcalibur v2.2 (Thermo Scientific) using assisting software i.e., GlycoMod (http://www.expasy.ch/tools/glycomod) and GlycoWorkBench v2.1 and manual de novo glycan sequencing as previously described [102, 103]. Glycan isomers were identified based on their monoisotopic precursor mass, MS/MS fragmentation pattern and their relative and absolute PGC-LC retention time [104]. The relative abundances of the individual $N$-glycans were determined from relative area-under-the-curve measurements based on extracted ion chromatograms performed for all charge states of the precursor ions using RawMeat v2.1 (Vast Scientific), QuantAnalysis software v2.1 (Bruker) and Skyline (64-bit) v20.1.0.76 [104]. The total relative level of all oligomannosidic $N$-glycans was determined as a proportion of the entire $N$-glycome. For that purpose, only $\mathrm{N}$-glycans observed above a limitof-quantitation threshold of $0.01 \%$ relative abundance were considered. Further, the relative distribution of the individual oligomannosidic $N$-glycans was determined based on their relative abundance as a proportion of all observed oligomannosidic $N$-glycans. Five major oligomannose species, M5-M9, some with at least two isobaric isomers were consistently identified across the investigated samples, Supplementary Data 1. Low levels of M4, M8 + Glc and M9 + Glc not fitting the common definition of oligomannose were observed in some samples and were excluded from the quantitative profiling of oligomannose. Supplementary Data 2 (cell lines) and Supplementary Data 3 (tissues) summarize key information of all identified glycans for each cancer type including details of the structure, composition, observed and theoretical molecular mass and mass deviation, PGCLC retention time, area-under-the-curve value and relative abundance of the oligomannosidic species.

\section{Lectin flow cytometry}

HL-60 cells (ATCC ${ }^{\circledR}$, CCL-240 ${ }^{\mathrm{TM}}$ ) were cultured in Roswell Park Memorial Institute-1640 media supplemented with $10 \%$ (v/v) heat-inactivated fetal bovine serum (Sigma-Aldrich) and maintained at $37^{\circ} \mathrm{C}$ with $5 \%$ $\mathrm{CO}_{2}$. Cells were pelleted by centrifugation at $300 \times \mathrm{g}$, washed twice in phosphate buffered saline (PBS), and resuspended in PBS with $1 \%(\mathrm{w} / \mathrm{v})$ bovine serum albumin (BSA, Sigma-Aldrich) before cell counting and viability determination using $0.4 \%(\mathrm{w} / \mathrm{v})$ trypan blue staining (Sigma-Aldrich). A total of $5 \times 10^{5}$ cells were used for each flow cytometry experiment. Cells were pelleted, washed once in $\mathrm{PBS} / 1 \% \mathrm{BSA}$, resuspended in $100 \mu \mathrm{l}$ concanavalin A-FITC (ConA-FITC, $1 \mu \mathrm{g} / \mathrm{ml}$, SigmaAldrich) in the presence or absence of $0.5 \mathrm{M}$ methyl- $\alpha$ D-mannopyranoside (Me- $\alpha$-Man) and then incubated in the dark on ice for $30 \mathrm{~min}$. Cultured HL-60 cells without ConA-FITC treatment were used as a control. After incubation, cells were washed twice with $\mathrm{PBS} / 1 \% \mathrm{BSA}$ and resuspended in $500 \mu \mathrm{lBS} / 1 \% \mathrm{BSA}$ for analysis on a CytoFLEX S flow cytometer (Beckman Coulter, Australia). The conjugated FITC was excited using a 488 $\mathrm{nm}$ laser and emission read at $525 \mathrm{~nm}$ using a 525/40 band-pass filter with a gain setting of 300. Data were acquired and stored in .fcs file format, imported into $\mathrm{R}$ v4.1.0 and analyzed with the R-package flowCore v2.2.0.

\section{Tissue microarray (TMA)-based matrix-assisted laser desorption/ionization mass spectrometry imaging (MALDI-MSI)}

A TMA slide with 15 different tumour tissues from patients suffering from various types of cancer and 
matching normal control tissues from healthy individuals (unpaired tumour/non-tumour sets, deposited on the TMA in technical duplicates) was obtained (Biochain, USA, catalogue \#T8235712-5, lot \#B306118). The patient metadata have been provided in Supplementary Table 5. The slide was pre-coated with indium tin oxide to generate a conductive surface for MALDI-MSI.

The TMA was rehydrated and processed using a standard procedure for citric acid-based antigen retrieval [105]. Briefly, the tissue sections were heated to $60^{\circ} \mathrm{C}$ for $1 \mathrm{~h}$ on a heating block, washed twice in $100 \%(\mathrm{v} / \mathrm{v})$ xylene for $5 \mathrm{~min}$ followed by serial dilutions in ethanol $(100 \%, 90 \%, 70 \%, 50 \%$, v/v) for 2 min each. Sections were then washed twice in Milli-Q water for $5 \mathrm{~min}$. Next, the slides were boiled in $10 \mathrm{mM}$ citraconic acid (pH 3.0) for $20 \mathrm{~min}$ on a steamer. Finally, tissue sections were immersed twice in $10 \mathrm{mM}$ ammonium bicarbonate for $1 \mathrm{~min}$ and dried at room temperature in a humidity chamber. Peptide- $N$-glycosidase F (PNGase F PRIME ${ }^{\mathrm{TM}}$; $\mathrm{N}$-Zyme Scientifics, USA) was sprayed onto the tissue sections using a TM-Sprayer (HTX-Imaging, USA) at a concentration of $0.1 \mu \mathrm{g} / \mu \mathrm{l}$, flow rate of $25 \mu \mathrm{l} / \mathrm{min}, 15$ passes, criss-cross pattern, velocity of $1200 \mathrm{~mm} / \mathrm{min}$, and track spacing of $3.0 \mathrm{~mm}$. The nitrogen gas pressure was maintained at 10 psi. Tissue sections were incubated at $37^{\circ} \mathrm{C}$ for $2 \mathrm{~h}$ in a humidity chamber. A homogenous matrix ( $\alpha$-cyano-4-hydroxycinnamic acid, $10 \mathrm{mg} / \mathrm{ml}$ in $50 \%$ (v/v) acetonitrile $/ 0.1 \%(\mathrm{v} / \mathrm{v})$ trifluoroacetic acid) was applied to tissues using the TM-sprayer. The applied settings were: 8 passes, $0.1 \mathrm{ml} / \mathrm{min}$ flow rate, 10 psi nitrogen pressure, $80^{\circ} \mathrm{C}$ capillary temperature, criss-cross pattern, velocity of $1200 \mathrm{~mm} / \mathrm{min}$, and track spacing of $3.0 \mathrm{~mm}$.

The MSI data were acquired using a rapifleX MALDI-TOF/TOF mass spectrometer (Bruker Daltonics, Germany) controlled by flexControl (v4) and flexImaging (v5.1). Instrument settings were: $m / z 920$ $3200,5 \mathrm{kHz}$ laser repetition rate and $2.5 \mathrm{GS} / \mathrm{s}$. A total of 400 shots were acquired using a smartbeam 3D laser at 35 $\mu \mathrm{m}$ spatial resolution. The instrument was calibrated ontissue using theoretical $\mathrm{m} / \mathrm{z}$ values of known glycans prior to data acquisition. The MALDI-MSI data were analyzed using SCiLS Lab v2016b, SCiLS (Bruker Daltonics, Germany). Raw data were pre-processed by baseline subtraction and normalization to the total ion count as previously shown $[84,85,105]$.

Following the MALDI-MSI analysis, the matrix was eluted from the slides using $70 \%(\mathrm{v} / \mathrm{v})$ ethanol and tissue sections were stained using hematoxylin-eosin (H\&E) staining to validate that the investigated tissue spots were from tumorigenic and non-tumour regions across the TMA using a standard protocol as described previously [105].

\section{Expression data of human a1,2-mannosidases}

Transcript (mRNA) expression data of MAN1A1, MAN1A2, MAN1B1 and MAN1C1 from paired and unpaired tumour and non-tumour tissues across 12 cancer types were obtained from the Gene Expression Omnibus (GEO) database (https://www.ncbi.nlm.nih. gov/geo/) (Supplementary Data 4A) [106, 107]. Projects with the following GEO accession IDs (primary site) were considered: GDS1375 (skin), GDS3975 (uterus), GDS4382 (colon), GD3837 (lung), GDS1210 (gastric), GDS1479 (bladder), GDS2835 (ovary), GDS4102 (pancreas), GDS3139 (breast), GDS505 (kidney), GDS1732 (thyroid) and GDS2545 (prostate). Only human cancer types covered by our literature survey and/or our collection of glycomics datasets were included in this analysis. Other inclusion criteria included the availability of data from both non-tumour and tumour (primary site) tissues from a minimum of five patients per cohort.

Transcript (mRNA) expression data of MAN1A1, MAN1A2, MAN1B1 and MAN1C1 from select cancer cell lines were obtained using the RNAseq NCI-60 data [108] via the CellMiner ${ }^{\mathrm{TM}}$ database (http://discover.nci. nih.gov/cellminer) (Supplementary Data 4B) [109]. Only cell lines from primary tumour sites and with matching glycomics data from whole cell lysates and/or microsomal fractions were included in this analysis to limit the variability among the compared samples by avoiding unwanted influence from the metastatic transformation. Thus, cancer cell lines from metastatic sites and where glycomics data only were available for the secretome were left out. Five cell lines matched these inclusion criteria i.e., HL-60 and CCRF-CEM (blood cancer), Hs578T (BC), SKOV3 (OvC) and A549 (lung cancer). The relative oligomannose abundance and the transcript levels of the four $\alpha 1$,2-mannosidases were normalized to 1 across the five cell lines. Correlation between the oligomannose and $\alpha 1,2$-mannosidase expression levels were determined using Pearson correlation.

The rates of simple somatic mutations (SSMs) of four $\alpha 1,2$-mannosidases were obtained from The Cancer Genome Atlas (TCGA) (https://www.cancer.gov/tcga) (Supplementary Data 4C) [110]. Data obtained from unique cancer primary sites including 11 projects with the following accession IDs (primary site) were considered: TCGA-SKCM (skin), TCGA-UCEC (uterus), TCGACOAD (colon), TCGA-LUSC (lung), TCGA-STAD (stomach/gastric), TCGA-BLCA (bladder), TCGA-OV (ovary), TCGA-BRCA (breast), TCGA-LIHC (liver), TCGA-KIRC (kidney) and TCGA-PRAD (prostate).

\section{Statistics}

Statistical tests of the glycomics data and the $\alpha 1,2-$ mannosidase expression data were performed using paired and unpaired one- or two-tailed Student's $t$-tests after testing for normality using the Kolmogorov-Smirnov test. Significance has been consistently indicated as ${ }^{*} p<0.05$ ), $\left.\left.{ }^{* *} p<0.001\right),{ }^{* * *} p<0.0001\right)$ while n.s. denotes a lack of significance $(p \geq 0.05)$. The number of patient samples 
(n) for the different tissue analyses has been indicated. Cell line glycoprofiling data were generated from at least two or three technical replicates for each experiment. Data have generally been plotted as the mean \pm standard deviation (SD) where $n \geq 3$.

\section{CONCLUSIONS}

Guided by a comprehensive literature survey pointing to a hitherto under-explored association between oligomannosylation and human cancers, we have here reinterrogated a large volume of PGC-LC-MS/MS glycomics datasets generated from a diverse set of cancer cell lines and valuable cohorts of patient tissues. Our quantitative glycomics data and supporting qualitative MALDI-MSI data demonstrate that the oligomannose content varies greatly across different tumour microenvironments and that some cancers show a trend towards increased oligomannosylation levels. Also deserving further exploration, the lectin flow cytometry data indicated that oligomannose may in some cancers form cell surface epitopes. Finally, data from well-curated cancer repositories suggested that aberrant expression of several $\alpha 1,2$-mannosidases may contribute to the modulation of oligomannose in some types of cancers.

Conclusively, this omics-centric study has compiled considerable volumes of robust data and revealed interesting trends in oligomannosylation and a1,2-mannosidase expression in several cancers that collectively serve as an important resource to further explore the role of oligomannosylation in human cancers.

\section{Abbreviations}

2-AB: 2-aminobenzoic acid; ALL: acute lymphocytic leukemia; AML: acute monocytic leukemia; APL: acute promyelocytic leukemia; APTS: 8-amino1,3,6-pyrenetrisulfonic acid; Asn: asparagine; BC: breast cancer; BCC: basal cell carcinoma; BlaCa: bladder cancer; BPH: benign prostatic hyperplasia; BSA: bovine serum albumin; CC: cholangiocarcinoma; CLL: chronic lymphocyte leukemia; ConA: concanavalin A; CRC: colorectal cancer; ER: endoplasmic reticulum; FF: fresh frozen; FFPE: formalin-fixed paraffin-embedded; Fuc: fucose; Gal: galactose; GC: gastric cancer; GEO: Gene Expression Omnibus; Glc: glucose; GlcNAc: $N$-acetylglucosamine; H\&E: hematoxylin and eosin; HCC: hepatocellular carcinoma; KC: kidney cancer; LC-MS/ MS: liquid chromatography tandem mass spectrometry; MALDI-MSI: matrix-assisted laser desorption/ ionization mass spectrometry imaging; Man: mannose; Me- $\alpha$-Man: methyl- $\alpha-D-m a n n o p y r a n o s i d e ; ~ N e u A c:$ $N$-acetylneuraminic acid; OC: oral cancer; OvC: ovarian cancer; PanCa: pancreas cancer; PBS: phosphate buffered saline; PCa: prostate cancer; PGC: porous graphitized carbon; SCC: squamous cell carcinoma; SD: standard deviation; SSM: simple somatic mutation; TC: thyroid cancer; TCGA: The Cancer Genome Atlas; TMA: tissue microarray.

\section{Author contributions}

Conceptualization, S.C. and M.T.A.; methodology, S.C., J.U. and A.E.D; software, S.C., A.E.D. and R.K.; validation, S.C., R.K. and M.T.A.; formal analysis, S.C., J.U. and R.K.; investigation, S.C., R.K. and M.T.A.; resources, A.E.D., R.K. and M.T.A.; data curation, S.C., R.K. and M.T.A.; writing - original draft preparation, S.C., R.K. and M.T.A.; writing-review and editing, S.C., J.U., L.Y.L., A.E.D., R.K. and M.T.A.; supervision, R.K. and M.T.A.; project administration, R.K. and M.T.A.; funding acquisition, R.K. and M.T.A. All authors have read and agreed to the published version of the manuscript.

\section{ACKNOWLEDGMENTS}

S.C. was supported by an International Macquarie Research Excellence Scholarship Program. J.U. was supported by a Macquarie Research Excellence Scholarship Program. A.E.D. was supported by the Griffith University Institute for Glycomics. R.K. was supported by an Early Career Fellowship from the Cancer Institute New South Wales. M.T.A. was supported by a Macquarie University Safety Net Grant. The authors thank Russel M. Vincent for valuable assistance with the acquisition and analysis of flow cytometry data.

\section{CONFLICTS OF INTEREST}

The authors have declared no conflict of interest.

\section{REFERENCES}

1. Varki A. Biological roles of glycans. Glycobiology. 2017; 27:3-49. https://doi.org/10.1093/glycob/cww086. [PubMed]

2. Moremen KW, Tiemeyer M, Nairn AV. Vertebrate protein glycosylation: diversity, synthesis and function. Nat Rev Mol Cell Biol. 2012; 13:448-62. https://doi.org/10.1038/ $\underline{\text { nrm3383. }}$ [PubMed]

3. Schjoldager KT, Narimatsu Y, Joshi HJ, Clausen H. Global view of human protein glycosylation pathways and functions. Nat Rev Mol Cell Biol. 2020; 21:729-49. https:// doi.org/10.1038/s41580-020-00294-X. [PubMed]

4. Eichler J. Protein glycosylation. Curr Biol. 2019; 29:R22931. https://doi.org/10.1016/i.cub.2019.01.003. [PubMed]

5. Varki A, Kornfeld S. Historical Background and Overview. Essentials of Glycobiology. Cold Spring Harbor (NY): Cold Spring Harbor Laboratory Press. 2017: Chapter 1. [PubMed]

6. Mikolajczyk K, Kaczmarek R, Czerwinski M. How glycosylation affects glycosylation: the role of N-glycans in 
glycosyltransferase activity. Glycobiology. 2020; 30:94169. https://doi.org/10.1093/glycob/cwaa041. [PubMed]

7. Nagae M, Yamaguchi Y, Taniguchi N, Kizuka Y. 3D Structure and Function of Glycosyltransferases Involved in $N$-glycan Maturation. Int J Mol Sci. 2020; 21:437. https:// doi.org/10.3390/ijms21020437. [PubMed]

8. Rini JM, Esko JD. Glycosyltransferases and GlycanProcessing Enzymes. Essentials of Glycobiology. Cold Spring Harbor (NY): Cold Spring Harbor Laboratory Press. 2017: Chapter 6. [PubMed]

9. Chung CY, Majewska NI, Wang Q, Paul JT, Betenbaugh MJ. SnapShot: N-Glycosylation Processing Pathways across Kingdoms. Cell. 2017; 171:258-58.e1. https://doi. org/10.1016/j.cell.2017.09.014. [ubMed]

10. Breitling J, Aebi M. N-linked protein glycosylation in the endoplasmic reticulum. Cold Spring Harb Perspect Biol. 2013; 5:a013359. https://doi.org/10.1101/cshperspect. a013359. [PubMed]

11. Kreisman LS, Cobb BA. Infection, inflammation and host carbohydrates: a Glyco-Evasion Hypothesis. Glycobiology. 2012; 22:1019-30. https://doi.org/10.1093/glycob/cws070. [PubMed]

12. Thaysen-Andersen M, Venkatakrishnan V, Loke I, Laurini C, Diestel S, Parker BL, Packer NH. Human neutrophils secrete bioactive paucimannosidic proteins from azurophilic granules into pathogen-infected sputum. J Biol Chem. 2015; 290:8789-802. https://doi.org/10.1074/jbc.M114.631622. [PubMed]

13. Loke I, Packer NH, Thaysen-Andersen M. Complementary LC-MS/MS-Based N-Glycan, N-Glycopeptide, and Intact N-Glycoprotein Profiling Reveals Unconventional Asn71-Glycosylation of Human Neutrophil Cathepsin G. Biomolecules. 2015; 5:1832-54. https://doi.org/10.3390/ biom5031832. [PubMed]

14. Loke I, Østergaard O, Heegaard NHH, Packer NH, ThaysenAndersen M. Paucimannose-Rich $N$-glycosylation of Spatiotemporally Regulated Human Neutrophil Elastase Modulates Its Immune Functions. Mol Cell Proteomics. 2017; 16:1507-27. https://doi.org/10.1074/mcp.M116.066746. [PubMed]

15. Tjondro HC, Ugonotti J, Kawahara R, Chatterjee S, Loke I, Chen S, Soltermann F, Hinneburg H, Parker BL, Venkatakrishnan V, Dieckmann R, Grant OC, Bylund J, et al. Hyper-truncated Asn355- and Asn391glycans modulate the activity of neutrophil granule myeloperoxidase. J Biol Chem. 2021; 296:100144. https:// doi.org/10.1074/jbc.RA120.016342. [PubMed]

16. Sethi MK, Kim H, Park CK, Baker MS, Paik YK, Packer NH, Hancock WS, Fanayan S, Thaysen-Andersen M. In-depth $\mathrm{N}$-glycome profiling of paired colorectal cancer and non-tumorigenic tissues reveals cancer-, stage- and EGFR-specific protein N-glycosylation. Glycobiology. 2015; 25:1064-78. https://doi.org/10.1093/glycob/cwv042. [PubMed]
17. Bieberich E. Synthesis, Processing, and Function of N-glycans in N-glycoproteins. Adv Neurobiol. 2014; 9:4770. https://doi.org/10.1007/978-1-4939-1154-7 3. [PubMed]

18. Schwarz F, Aebi M. Mechanisms and principles of N-linked protein glycosylation. Curr Opin Struct Biol. 2011; 21:57682. https://doi.org/10.1016/j.sbi.2011.08.005. [PubMed]

19. Helenius A, Aebi M. Roles of N-linked glycans in the endoplasmic reticulum. Annu Rev Biochem. 2004; 73:1019-49. https://doi.org/10.1146/annurev. biochem.73.011303.073752. [PubMed]

20. Aebi M, Bernasconi R, Clerc S, Molinari M. N-glycan structures: recognition and processing in the ER. Trends Biochem Sci. 2010; 35:74-82. https://doi.org/10.1016/j. tibs.2009.10.001. [uㅏㄹed]

21. Loke I, Kolarich D, Packer NH, Thaysen-Andersen M. Emerging roles of protein mannosylation in inflammation and infection. Mol Aspects Med. 2016; 51:31-55. https:// doi.org/10.1016/j.mam.2016.04.004. [PubMed]

22. Kang PB, Azad AK, Torrelles JB, Kaufman TM, Beharka A, Tibesar E, DesJardin LE, Schlesinger LS. The human macrophage mannose receptor directs Mycobacterium tuberculosis lipoarabinomannan-mediated phagosome biogenesis. J Exp Med. 2005; 202:987-99. https://doi. org/10.1084/jem.20051239. [PubMed]

23. Hare NJ, Lee LY, Loke I, Britton WJ, Saunders BM, Thaysen-Andersen M. Mycobacterium tuberculosis Infection Manipulates the Glycosylation Machinery and the N-Glycoproteome of Human Macrophages and Their Microparticles. J Proteome Res. 2017; 16:247-63. https:// doi.org/10.1021/acs.jproteome.6b00685. [PubMed]

24. Pak J, Pu Y, Zhang ZT, Hasty DL, Wu XR. Tamm-Horsfall protein binds to type 1 fimbriated Escherichia coli and prevents E. coli from binding to uroplakin Ia and $\mathrm{Ib}$ receptors. J Biol Chem. 2001; 276:9924-30. https://doi. org/10.1074/jbc.M008610200. [PubMed]

25. Monticielo OA, Mucenic T, Xavier RM, Brenol JC, Chies JA. The role of mannose-binding lectin in systemic lupus erythematosus. Clin Rheumatol. 2008; 27:413-19. https:// doi.org/10.1007/s10067-008-0838-8. [PubMed]

26. Peixoto A, Relvas-Santos M, Azevedo R, Santos LL, Ferreira JA. Protein Glycosylation and Tumor Microenvironment Alterations Driving Cancer Hallmarks. Front Oncol. 2019; 9:380. https://doi.org/10.3389/ fonc.2019.00380. [PubMed]

27. Christiansen MN, Chik J, Lee L, Anugraham M, Abrahams JL, Packer NH. Cell surface protein glycosylation in cancer. Proteomics. 2014; 14:525-46. https://doi.org/10.1002/ pmic.201300387. [PubMed]

28. Stowell SR, Ju T, Cummings RD. Protein glycosylation in cancer. Annu Rev Pathol. 2015; 10:473-510. https://doi. org/10.1146/annurev-pathol-012414-040438. [PubMed]

29. Munkley J, Elliott DJ. Hallmarks of glycosylation in cancer. Oncotarget. 2016; 7:35478-89. https://doi.org/10.18632/ oncotarget.8155. [PubMed] 
30. Taniguchi N, Kizuka Y. Glycans and cancer: role of $\mathrm{N}$-glycans in cancer biomarker, progression and metastasis, and therapeutics. Adv Cancer Res. 2015; 126:11-51. https:// doi.org/10.1016/bs.acr.2014.11.001. [PubMed]

31. Pinho SS, Reis CA. Glycosylation in cancer: mechanisms and clinical implications. Nat Rev Cancer. 2015; 15:540 55. https://doi.org/10.1038/nrc3982. [PubMed]

32. Merlotti A, Malizia AL, Michea P, Bonte PE, Goudot C, Carregal MS, Nuñez N, Sedlik C, Ceballos A, Soumelis V, Amigorena S, Geffner J, Piaggio E, Sabatte J. Aberrant fucosylation enables breast cancer clusterin to interact with dendritic cell-specific ICAM-grabbing non-integrin (DCSIGN). Oncoimmunology. 2019; 8:e1629257. https://doi.or g/10.1080/2162402X.2019.1629257. [PubMed]

33. Magalhães A, Duarte HO, Reis CA. Aberrant Glycosylation in Cancer: A Novel Molecular Mechanism Controlling Metastasis. Cancer Cell. 2017; 31:733-35. https://doi. org/10.1016/j.ccell.2017.05.012. [PubMed]

34. Cui H, Lin Y, Yue L, Zhao X, Liu J. Differential expression of the $\alpha 2,3$-sialic acid residues in breast cancer is associated with metastatic potential. Oncol Rep. 2011; 25:1365-71. https://doi.org/10.3892/or.2011.1192. [PubMed]

35. Park JJ, Lee M. Increasing the $\alpha 2,6$ sialylation of glycoproteins may contribute to metastatic spread and therapeutic resistance in colorectal cancer. Gut Liver. 2013; 7:629-41. https://doi.org/10.5009/gn1.2013.7.6.629. [PubMed]

36. Sethi MK, Thaysen-Andersen M, Smith JT, Baker MS, Packer NH, Hancock WS, Fanayan S. Comparative $\mathrm{N}$-glycan profiling of colorectal cancer cell lines reveals unique bisecting GlcNAc and $\alpha-2,3$-linked sialic acid determinants are associated with membrane proteins of the more metastatic/aggressive cell lines. J Proteome Res. 2014; 13:277-88. https://doi.org/10.1021/pr400861m. [PubMed]

37. Tan Z, Cao L, Wu Y, Wang B, Song Z, Yang J, Cheng L, Yang X, Zhou X, Dai Z, Li X, Guan F. Bisecting GlcNAc modification diminishes the pro-metastatic functions of small extracellular vesicles from breast cancer cells. J Extracell Vesicles. 2020; 10:e12005. https://doi. org/10.1002/jev2.12005. [PubMed]

38. Chatterjee S, Lee LY, Kawahara R, Abrahams JL, Adamczyk B, Anugraham M, Ashwood C, Sumer-Bayraktar Z, Briggs MT, Chik JHL, Everest-Dass A, Förster S, Hinneburg H, et al. Protein Paucimannosylation Is an Enriched N-Glycosylation Signature of Human Cancers. Proteomics. 2019; 19:e1900010. https://doi.org/10.1002/ pmic.201900010. [PubMed]

39. Yang G, Tan Z, Lu W, Guo J, Yu H, Yu J, Sun C, Qi X, Li Z, Guan F. Quantitative glycome analysis of N-glycan patterns in bladder cancer vs normal bladder cells using an integrated strategy. J Proteome Res. 2015; 14:639-53. https://doi.org/10.1021/pr5006026. [PubMed]

40. de Leoz ML, Young LJ, An HJ, Kronewitter SR, Kim J, Miyamoto S, Borowsky AD, Chew HK, Lebrilla CB. High-mannose glycans are elevated during breast cancer progression. Mol Cell Proteomics. 2011; 10:M110.002717. https://doi.org/10.1074/mcp.M110.002717. [PubMed]

41. Park DD, Phoomak C, Xu G, Olney LP, Tran KA, Park SS, Haigh NE, Luxardi G, Lert-Itthiporn W, Shimoda M, Li Q, Matoba N, Fierro F, et al. Metastasis of cholangiocarcinoma is promoted by extended high-mannose glycans. Proc Natl Acad Sci U S A. 2020; 117:7633-44. https://doi. org/10.1073/pnas.1916498117. [PubMed]

42. Mittal $P$, Briggs $M$, Klingler-Hoffmann $M$, Kaur G, Packer NH, Oehler MK, Hoffmann P. Altered N-linked glycosylation in endometrial cancer. Anal Bioanal Chem. 2021; 413:2721-33. https://doi.org/10.1007/s00216-02003039-z. [PubMed]

43. Heijs B, Holst-Bernal S, de Graaff MA, Briaire-de Bruijn IH, Rodriguez-Girondo M, van de Sande MAJ, Wuhrer M, McDonnell LA, Bovée JVM. Molecular signatures of tumor progression in myxoid liposarcoma identified by N-glycan mass spectrometry imaging. Lab Invest. 2020; 100:125261. https://doi.org/10.1038/s41374-020-0435-2. [PubMed]

44. Ruhaak LR, Taylor SL, Stroble C, Nguyen UT, Parker EA, Song T, Lebrilla CB, Rom WN, Pass H, Kim K, Kelly K, Miyamoto S. Differential N-Glycosylation Patterns in Lung Adenocarcinoma Tissue. J Proteome Res. 2015; 14:4538-49. https://doi.org/10.1021/acs. jproteome.5b00255. [PubMed]

45. Briggs MT, Condina MR, Ho YY, Everest-Dass AV, Mittal P, Kaur G, Oehler MK, Packer NH, Hoffmann P. MALDI Mass Spectrometry Imaging of Early- and Late-Stage Serous Ovarian Cancer Tissue Reveals Stage-Specific N-Glycans. Proteomics. 2019; 19:e1800482. https://doi. org/10.1002/pmic.201800482. [PubMed]

46. Chen YT, Chong YM, Cheng CW, Ho CL, Tsai HW, Kasten FH, Chen YL, Chang CF. Identification of novel tumor markers for oral squamous cell carcinoma using glycoproteomic analysis. Clin Chim Acta. 2013; 420:45-53. https://doi.org/10.1016/j.cca.2012.10.019. [PubMed]

47. Gilgunn S, Murphy K, Stöckmann H, Conroy PJ, Murphy TB, Watson RW, O'Kennedy RJ, Rudd PM, Saldova R. Glycosylation in Indolent, Significant and Aggressive Prostate Cancer by Automated High-Throughput $N$-Glycan Profiling. Int J Mol Sci. 2020; 21:9233. https://doi. org/10.3390/ijms21239233. [PubMed]

48. Ozcan S, Barkauskas DA, Renee Ruhaak L, Torres J, Cooke CL, An HJ, Hua S, Williams CC, Dimapasoc LM, Han Kim J, Camorlinga-Ponce M, Rocke D, Lebrilla CB, Solnick JV. Serum glycan signatures of gastric cancer. Cancer Prev Res (Phila). 2014; 7:226-35. https://doi.org/10.1158/1940-6207. CAPR-13-0235. [PubMed]

49. Nie H, Liu X, Zhang Y, Li T, Zhan C, Huo W, He A, Yao Y, Jin Y, Qu Y, Sun XL, Li Y. Specific N-glycans of Hepatocellular Carcinoma Cell Surface and the Abnormal Increase of Core- $\alpha-1$, 6-fucosylated Triantennary Glycan via N-acetylglucosaminyltransferases-IVa Regulation. Sci Rep. 2015; 5:16007. https://doi.org/10.1038/srep16007. [PubMed] 
50. Drake RR, McDowell C, West C, David F, Powers TW, Nowling T, Bruner E, Mehta AS, Angel PM, Marlow LA, Tun HW, Copland JA. Defining the human kidney $\mathrm{N}$-glycome in normal and cancer tissues using MALDI imaging mass spectrometry. J Mass Spectrom. 2020; 55:e4490. https://doi.org/10.1002/jms.4490. [PubMed]

51. McDowell CT, Klamer Z, Hall J, West CA, Wisniewski L, Powers TW, Angel PM, Mehta AS, Lewin DN, Haab BB, Drake RR. Imaging Mass Spectrometry and Lectin Analysis of N-Linked Glycans in Carbohydrate Antigen-Defined Pancreatic Cancer Tissues. Mol Cell Proteomics. 2020; 20:100012. Epub ahead of print. https://doi.org/10.1074/ mcp.RA120.002256. [PubMed]

52. Koçak ÖF, Kayili HM, Albayrak M, Yaman ME, Kadığlu Y, Salih B. N-glycan profiling of papillary thyroid carcinoma tissues by MALDI-TOF-MS. Anal Biochem. 2019; 584:113389. https://doi.org/10.1016/j. ab.2019.113389. [PubMed]

53. Liu X, Nie H, Zhang Y, Yao Y, Maitikabili A, Qu Y, Shi S, Chen C, Li Y. Cell surface-specific N-glycan profiling in breast cancer. PLoS One. 2013; 8:e72704. https://doi. org/10.1371/journal.pone.0072704. [PubMed]

54. Li Q, Li G, Zhou Y, Zhang X, Sun M, Jiang H, Yu G. Comprehensive N-Glycome Profiling of Cells and Tissues for Breast Cancer Diagnosis. J Proteome Res. 2019; 18:2559-70. https://doi.org/10.1021/acs. iproteome.9b00073. [PubMed]

55. Goetz JA, Mechref Y, Kang P, Jeng MH, Novotny MV. Glycomic profiling of invasive and non-invasive breast cancer cells. Glycoconj J. 2009; 26:117-31. https://doi. org/10.1007/s10719-008-9170-4. [PubMed]

56. Talabnin K, Talabnin C, Ishihara M, Azadi P. Increased expression of the high-mannose M6N2 and NeuAc3H3N3M3N2F tri-antennary $N$-glycans in cholangiocarcinoma. Oncol Lett. 2018; 15:1030-36. https:// doi.org/10.3892/ol.2017.7384. [PubMed]

57. Boyaval F, Van Zeijl R, Dalebout H, Holst S, van Pelt G, Fariña-Sarasqueta A, Mesker W, Tollenaar R, Morreau H, Wuhrer M, Heijs B. N-glycomic signature of stage II colorectal cancer and its association with the tumor microenvironment. Mol Cell Proteomics. 2021; 20:100057. Epub ahead of print. https://doi.org/10.1074/mcp. $\underline{\text { RA120.002215. [PubMed] }}$

58. Kaprio T, Satomaa T, Heiskanen A, Hokke CH, Deelder AM, Mustonen H, Hagström J, Carpen O, Saarinen J, Haglund C. $\mathrm{N}$-glycomic profiling as a tool to separate rectal adenomas from carcinomas. Mol Cell Proteomics. 2015; 14:277-88. https://doi.org/10.1074/mcp.M114.041632. [PubMed]

59. Zhang D, Xie Q, Wang Q, Wang Y, Miao J, Li L, Zhang T, Cao X, Li Y. Mass spectrometry analysis reveals aberrant $\mathrm{N}$-glycans in colorectal cancer tissues. Glycobiology. 2019; 29:372-84. https://doi.org/10.1093/glycob/cwz005. [PubMed]

60. Coura MMA, Barbosa EA, Brand GD, Bloch C Jr, de Sousa JB. Identification of Differential N-Glycan Compositions in the Serum and Tissue of Colon Cancer Patients by Mass Spectrometry. Biology (Basel). 2021; 10:343. https://doi. org/10.3390/biology10040343. [PubMed]

61. Wang X, Deng Z, Huang C, Zhu T, Lou J, Wang L, Li Y. Differential N-glycan patterns identified in lung adenocarcinoma by $\mathrm{N}$-glycan profiling of formalin-fixed paraffin-embedded (FFPE) tissue sections. J Proteomics. 2018; 172:1-10. https://doi.org/10.1016/j.jprot.2017.11.010. [PubMed]

62. Liang Y, Han P, Wang T, Ren H, Gao L, Shi P, Zhang S, Yang A, Li Z, Chen M. Stage-associated differences in the serum $N$ - and $O$-glycan profiles of patients with non-small cell lung cancer. Clin Proteomics. 2019; 16:20. https://doi. org/10.1186/s12014-019-9240-6. [PubMed]

63. Hu Y, Pan J, Shah P, Ao M, Thomas SN, Liu Y, Chen L, Schnaubelt M, Clark DJ, Rodriguez H, Boja ES, Hiltke T, Kinsinger CR, et al, and Clinical Proteomic Tumor Analysis Consortium. Integrated Proteomic and Glycoproteomic Characterization of Human High-Grade Serous Ovarian Carcinoma. Cell Rep. 2020; 33:108276. https://doi. org/10.1016/j.celrep.2020.108276. [PubMed]

64. Everest-Dass AV, Briggs MT, Kaur G, Oehler MK, Hoffmann P, Packer NH. N-glycan MALDI Imaging Mass Spectrometry on Formalin-Fixed Paraffin-Embedded Tissue Enables the Delineation of Ovarian Cancer Tissues. Mol Cell Proteomics. 2016; 15:3003-16. https://doi.org/10.1074/ mcp.M116.059816. [PubMed]

65. Powers TW, Neely BA, Shao Y, Tang H, Troyer DA, Mehta AS, Haab BB, Drake RR. MALDI imaging mass spectrometry profiling of $\mathrm{N}$-glycans in formalin-fixed paraffin embedded clinical tissue blocks and tissue microarrays. PLoS One. 2014; 9:e106255. https://doi. org/10.1371/journal.pone.0106255. [PubMed]

66. Wang D, Dafik L, Nolley R, Huang W, Wolfinger RD, Wang LX, Peehl DM. Anti-Oligomannose Antibodies as Potential Serum Biomarkers of Aggressive Prostate Cancer. Drug Dev Res. 2013; 74:65-80. https://doi.org/10.1002/ ddr.21063. [PubMed]

67. Powers TW, Holst S, Wuhrer M, Mehta AS, Drake RR. Two-Dimensional N-Glycan Distribution Mapping of Hepatocellular Carcinoma Tissues by MALDI-Imaging Mass Spectrometry. Biomolecules. 2015; 5:2554-72. https://doi.org/10.3390/biom5042554. [PubMed]

68. West CA, Wang M, Herrera H, Liang H, Black A, Angel PM, Drake RR, Mehta AS. N-Linked Glycan Branching and Fucosylation Are Increased Directly in Hcc Tissue As Determined through in Situ Glycan Imaging. J Proteome Res. 2018; 17:3454-62. https://doi.org/10.1021/acs. iproteome.8b00323. [PubMed]

69. Lee LY, Lin CH, Fanayan S, Packer NH, Thaysen-Andersen M. Differential site accessibility mechanistically explains subcellular-specific N-glycosylation determinants. Front Immunol. 2014; 5:404. https://doi.org/10.3389/ fimmu.2014.00404. [PubMed] 
70. Rudd PM, Dwek RA. Glycosylation: heterogeneity and the 3D structure of proteins. Crit Rev Biochem Mol Biol. 1997; 32:1-100. https://doi.org/10.3109/10409239709085144. [PubMed]

71. Thaysen-Andersen M, Packer NH. Site-specific glycoproteomics confirms that protein structure dictates formation of $\mathrm{N}$-glycan type, core fucosylation and branching. Glycobiology. 2012; 22:1440-52. https://doi. org/10.1093/glycob/cws110. [PubMed]

72. Legler K, Rosprim R, Karius T, Eylmann K, Rossberg M, Wirtz RM, Müller V, Witzel I, Schmalfeldt B, MildeLangosch K, Oliveira-Ferrer L. Reduced mannosidase MAN1A1 expression leads to aberrant N-glycosylation and impaired survival in breast cancer. $\mathrm{Br} \mathrm{J}$ Cancer. 2018; 118:847-56. https://doi.org/10.1038/bjc.2017.472. [PubMed]

73. Li H, Wang G, Yu Y, Jian W, Zhang D, Wang Y, Wang T, Meng Y, Yuan C, Zhang C. $\alpha$-1,2-Mannosidase MAN1C1 Inhibits Proliferation and Invasion of Clear Cell Renal Cell Carcinoma. J Cancer. 2018; 9:4618-26. https://doi. org/10.7150/jca.27673. [PubMed]

74. Wang HF, Wu JH, Gai JW, Yang SQ, Ma QT, Ma HS, Feng Q. MAN1B1 is associated with poor prognosis and modulates proliferation and apoptosis in bladder cancer. Gene. 2018; 679:314-19. https://doi.org/10.1016/j. gene.2018.09.022. [PubMed]

75. Kronewitter SR, An HJ, de Leoz ML, Lebrilla CB, Miyamoto S, Leiserowitz GS. The development of retrosynthetic glycan libraries to profile and classify the human serum N-linked glycome. Proteomics. 2009; 9:298694. https://doi.org/10.1002/pmic.200800760. [PubMed]

76. Clerc F, Reiding KR, Jansen BC, Kammeijer GS, Bondt A, Wuhrer M. Human plasma protein N-glycosylation. Glycoconj J. 2016; 33:309-43. https://doi.org/10.1007/ s10719-015-9626-2. [PubMed]

77. Blazev R, Ashwood C, Abrahams JL, Chung LH, Francis D, Yang P, Watt KI, Qian H, Quaife-Ryan GA, Hudson JE, Gregorevic P, Thaysen-Andersen M, Parker BL. Integrated Glycoproteomics Identifies a Role of N-Glycosylation and Galectin-1 on Myogenesis and Muscle Development. Mol Cell Proteomics. 2020; 20:100030. Epub ahead of print. https://doi.org/10.1074/ mcp.RA120.002166. [PubMed]

78. Steentoft C, Migliorini D, King TR, Mandel U, June CH, Posey AD Jr. Glycan-directed CAR-T cells. Glycobiology. 2018; 28:656-69. https://doi.org/10.1093/glycob/cwy008. [PubMed]

79. Guo Y, Feinberg H, Conroy E, Mitchell DA, Alvarez R, Blixt O, Taylor ME, Weis WI, Drickamer K. Structural basis for distinct ligand-binding and targeting properties of the receptors DC-SIGN and DC-SIGNR. Nat Struct Mol Biol. 2004; 11:591-98. https://doi.org/10.1038/nsmb784. [PubMed]
80. Feinberg H, Rowntree TJ, Tan SL, Drickamer K, Weis WI, Taylor ME. Common polymorphisms in human langerin change specificity for glycan ligands. J Biol Chem. 2013; 288:36762-71. https://doi.org/10.1074/jbc.M113.528000. [PubMed]

81. Feinberg H, Jégouzo SAF, Rex MJ, Drickamer K, Weis WI, Taylor ME. Mechanism of pathogen recognition by human dectin-2. J Biol Chem. 2017; 292:13402-14. https://doi. org/10.1074/jbc.M117.799080. [PubMed]

82. Stavenhagen K, Laan LC, Gao C, Mehta AY, HeimburgMolinaro J, Glickman JN, van Die I, Cummings RD. Tumor cells express pauci- and oligomannosidic N-glycans in glycoproteins recognized by the mannose receptor (CD206). Cell Mol Life Sci. 2021; 78:5569-85. https://doi. org/10.1007/s00018-021-03863-1. [PubMed]

83. Gao C, Stavenhagen K, Eckmair B, McKitrick TR, Mehta AY, Matsumoto Y, McQuillan AM, Hanes MS, Eris D, Baker KJ, Jia N, Wei M, Heimburg-Molinaro J, et al. Differential recognition of oligomannose isomers by glycanbinding proteins involved in innate and adaptive immunity. Sci Adv. 2021; 7:eabf6834. https://doi.org/10.1126/sciadv. abf6834. [PubMed]

84. Drake RR, Powers TW, Jones EE, Bruner E, Mehta AS, Angel PM. MALDI Mass Spectrometry Imaging of N-Linked Glycans in Cancer Tissues. Adv Cancer Res. 2017; 134:85116. https://doi.org/10.1016/bs.acr.2016.11.009. [PubMed]

85. Drake RR, Powers TW, Norris-Caneda K, Mehta AS, Angel PM. In Situ Imaging of N-Glycans by MALDI Imaging Mass Spectrometry of Fresh or Formalin-Fixed ParaffinEmbedded Tissue. Curr Protoc Protein Sci. 2018; 94:e68. https://doi.org/10.1002/cpps.68. [PubMed]

86. Kawahara R, Recuero S, Srougi M, Leite KRM, Thaysen-Andersen M, Palmisano G. The Complexity and Dynamics of the Tissue Glycoproteome Associated With Prostate Cancer Progression. Mol Cell Proteomics. 2021; 20:100026. Epub ahead of print. https://doi.org/10.1074/ mep.RA120.002320. [PubMed]

87. Chernykh A, Kawahara R, Thaysen-Andersen M. Towards structure-focused glycoproteomics. Biochem Soc Trans. 2021; 49:161-86. https://doi.org/10.1042/BST20200222. [PubMed]

88. Liu L, Borlak J. Advances in Liver Cancer Stem Cell Isolation and their Characterization. Stem Cell Rev Rep. 2021; 17:1215-38. https://doi.org/10.1007/s12015-02010114-6. [PubMed]

89. Papatheodorou I, Moreno P, Manning J, Fuentes AM, George N, Fexova S, Fonseca NA, Füllgrabe A, Green M, Huang N, Huerta L, Iqbal H, Jianu M, et al. Expression Atlas update: from tissues to single cells. Nucleic Acids Res. 2020; 48:D77-83. https://doi.org/10.1093/nar/gkz947. [PubMed]

90. Lash AE, Tolstoshev CM, Wagner L, Schuler GD, Strausberg RL, Riggins GJ, Altschul SF. SAGEmap: a 
public gene expression resource. Genome Res. 2000; 10:1051-60. https://doi.org/10.1101/gr.10.7.1051. [PubMed]

91. Goldman MJ, Craft B, Hastie M, Repečka K, McDade F, Kamath A, Banerjee A, Luo Y, Rogers D, Brooks AN, Zhu J, Haussler D. Visualizing and interpreting cancer genomics data via the Xena platform. Nat Biotechnol. 2020; 38:675-78. https://doi.org/10.1038/s41587-0200546-8. [PubMed]

92. Jin ZC, Kitajima T, Dong W, Huang YF, Ren WW, Guan F, Chiba Y, Gao XD, Fujita M. Genetic disruption of multiple $\alpha 1,2$-mannosidases generates mammalian cells producing recombinant proteins with high-mannose-type $N$-glycans. J Biol Chem. 2018; 293:5572-84. https://doi.org/10.1074/jbc. M117.813030. [PubMed]

93. Liu T, Zhang S, Chen J, Jiang K, Zhang Q, Guo K, Liu Y. The transcriptional profiling of glycogenes associated with hepatocellular carcinoma metastasis. PLoS One. 2014; 9:e107941. https://doi.org/10.1371/journal.pone.0107941. [PubMed]

94. Hamester F, Legler K, Wichert B, Kelle N, Eylmann K, Rossberg M, Ding Y, Kürti S, Schmalfeldt B, MildeLangosch K, Oliveira-Ferrer L. Prognostic relevance of the Golgi mannosidase MAN1A1 in ovarian cancer: impact of $\mathrm{N}$-glycosylation on tumour cell aggregation. Br J Cancer. 2019; 121:944-53. https://doi.org/10.1038/s41416-0190607-2. [PubMed]

95. Cheng PW, Davidson S, Bhat G. Markers of malignant prostate cancer cells: Golgi localization of $\alpha$-mannosidase 1A at GM130-GRASP65 site and appearance of high mannose N-glycans on cell surface. Biochem Biophys Res Commun. 2020; 527:406-10. https://doi.org/10.1016/j. bbrc.2020.03.168. [PubMed]

96. Tu HC, Hsiao YC, Yang WY, Tsai SL, Lin HK, Liao CY, Lu JW, Chou YT, Wang HD, Yuh CH. Up-regulation of golgi $\alpha$-mannosidase IA and down-regulation of golgi $\alpha$-mannosidase IC activates unfolded protein response during hepatocarcinogenesis. Hepatol Commun. 2017; 1:230-47. https://doi.org/10.1002/hep4.1032. [PubMed]

97. Gudelj I, Lauc G, Pezer M. Immunoglobulin G glycosylation in aging and diseases. Cell Immunol. 2018; 333:65-79. https://doi.org/10.1016/j.cellimm.2018.07.009. [PubMed]

98. Maupin KA, Liden D, Haab BB. The fine specificity of mannose-binding and galactose-binding lectins revealed using outlier motif analysis of glycan array data. Glycobiology. 2012; 22:160-69. https://doi.org/10.1093/ glycob/cwr128. [PubMed]

99. Briard JG, Jiang H, Moremen KW, Macauley MS, Wu P. Cell-based glycan arrays for probing glycan-glycan binding protein interactions. Nat Commun. 2018; 9:880. https://doi. org/10.1038/s41467-018-03245-5. [PubMed]

100. Jensen PH, Karlsson NG, Kolarich D, Packer NH. Structural analysis of $\mathrm{N}$ - and $\mathrm{O}$-glycans released from glycoproteins. Nat Protoc. 2012; 7:1299-310. https://doi.org/10.1038/ nprot.2012.063. [PubMed]
101. Hinneburg H, Chatterjee S, Schirmeister F, Nguyen-Khuong T, Packer NH, Rapp E, Thaysen-Andersen M. Post-Column Make-Up Flow (PCMF) Enhances the Performance of Capillary-Flow PGC-LC-MS/MS-Based Glycomics. Anal Chem. 2019; 91:4559-67. https://doi.org/10.1021/acs. analchem.8b05720. [PubMed]

102. Abrahams JL, Campbell MP, Packer NH. Building a PGCLC-MS N-glycan retention library and elution mapping resource. Glycoconj J. 2018; 35:15-29. https://doi. org/10.1007/s10719-017-9793-4. [PubMed]

103. Everest-Dass AV, Kolarich D, Campbell MP, Packer NH. Tandem mass spectra of glycan substructures enable the multistage mass spectrometric identification of determinants on oligosaccharides. Rapid Commun Mass Spectrom. 2013; 27:931-39. https://doi.org/10.1002/rcm.6527. [PubMed]

104. Ashwood C, Lin CH, Thaysen-Andersen M, Packer NH. Discrimination of Isomers of Released N- and O-Glycans Using Diagnostic Product Ions in Negative Ion PGC-LCESI-MS/MS. J Am Soc Mass Spectrom. 2018; 29:1194209. https://doi.org/10.1007/s13361-018-1932-z. [PubMed]

105. Briggs MT, Ho YY, Kaur G, Oehler MK, Everest-Dass AV, Packer NH, Hoffmann P. N-Glycan matrix-assisted laser desorption/ionization mass spectrometry imaging protocol for formalin-fixed paraffin-embedded tissues. Rapid Commun Mass Spectrom. 2017; 31:825-41. https://doi. org $/ 10.1002 / \mathrm{rcm} .7845$. [PubMed]

106. Edgar R, Domrachev M, Lash AE. Gene Expression Omnibus: NCBI gene expression and hybridization array data repository. Nucleic Acids Res. 2002; 30:207-10. https://doi.org/10.1093/nar/30.1.207. [PubMed]

107. Barrett T, Wilhite SE, Ledoux P, Evangelista C, Kim IF, Tomashevsky M, Marshall KA, Phillippy KH, Sherman PM, Holko M, Yefanov A, Lee H, Zhang N, et al. NCBI GEO: archive for functional genomics data sets--update. Nucleic Acids Res. 2013; 41:D991-95. https://doi.org/10.1093/nar/ gks1193. [PubMed]

108. Reinhold WC, Varma S, Sunshine M, Elloumi F, OforiAtta K, Lee S, Trepel JB, Meltzer PS, Doroshow JH, Pommier Y. RNA Sequencing of the NCI-60: Integration into CellMiner and CellMiner CDB. Cancer Res. 2019; 79:3514-24. https://doi.org/10.1158/0008-5472.CAN-182047. [PubMed]

109. Shankavaram UT, Varma S, Kane D, Sunshine M, Chary KK, Reinhold WC, Pommier Y, Weinstein JN. CellMiner: a relational database and query tool for the NCI-60 cancer cell lines. BMC Genomics. 2009; 10:277. https://doi. org/10.1186/1471-2164-10-277. [PubMed]

110. Tomczak K, Czerwińska P, Wiznerowicz M. The Cancer Genome Atlas (TCGA): an immeasurable source of knowledge. Contemp Oncol (Pozn). 2015; 19:A68-77. https://doi.org/10.5114/wo.2014.47136. [PubMed] 